\title{
Toplumsal Olaylara Dair Episodik ve Semantik Bellek Süreçlerinin Heyecanlanma Düzeyi ile İliş̧kisinin Yaş ve Heyecanın Ölçüm Türü Açısından İncelenmesi
}

\section{Episodic and Semantic Memory Processes Regarding Public Events and Their Relationship with Arousal Level, Age and Measurement Type}

\author{
Berivan Ece ${ }^{1}\left(\mathbb{0}\right.$, Sezin Öner ${ }^{2}$ (), Sami Gülgöz ${ }^{3}$ (])
}

'Öğr. Görevlisi, Koç Üniversitesi, İnsani Bilimler ve Edebiyat Fakültesi, Psikoloji Bölümü, İstanbul, Türkiye

${ }^{2}$ Dr. Öğr. Üyesi, Kadir Has Üniversitesi, İktisadi, İdari ve Sosyal Bilimler Fakültesi, Psikoloji Bölümü, İstanbul, Türkiye ${ }^{3}$ Prof. Dr., Koç Üniversitesi, İnsani Bilimler ve Edebiyat Fakültesi, Psikoloji Bölümü, İstanbul, Türkiye

ORCID: B.E. 0000-0003-1756-9685

S.Ö. 0000-0001-8124-3554

S.G. 0000-0002-1262-2347

Sorumlu yazar/Corresponding author: Berivan Ece,

Koç Üniversitesi, İnsani Bilimler ve Edebiyat Fakültesi, Psikoloji Bölümü, İstanbul, Türkiye E-posta/E-mail: beceusta@ku.edu.tr

Başvuru/Submitted: 12.10 .2018 Revizyon Talebi/Revision Requested: 12.10.2018

Son Revizyon/Last Revision Received: 07.01.2020

Kabul/Accepted: 13.01 .2020

Online Yayın/Published Online: 10.04.2020

Atıf/Citation: Ece, B., Oner, S., Gulgoz, S. Toplumsal olaylara dair episodik ve semantik bellek süreçlerinin heyecanlanma düzeyi ile ilişkisinin yaş ve heyecanın ölçüm türü açısından incelenmesi. Psikoloji Çalışmaları Studies in Psychology. Advance online publication.

https://doi.org/10.26650/SP2018-0028

\section{ÖZ}

Araştırmanın temel amacı toplumsal olaylara dair episodik (EB) ve semantik bellek (SB) süreçleri ile heyecanlanma arasındaki ilişkiyi ve bu ilişkinin yaş grupları arasında farklılıklar gösterip göstermediğini, öz-değerlendirmelere dayanan heyecanlanma ile fizyolojik ölçümlerle saptanan heyecanlanma düzeyi arasındaki tutarlılığı ve olayların fenomonolojik özelliklerini bellek türüne ve heyecanlanma düzeyine göre incelemektir. Bu amaçla, 18-25 yaş arası 32 genç yetişkin bireyden $($ Ort. $=20.60, S S=2.22), 40-55$ yaş arası 33 orta yaş yetişkin bireyden (Ort. $=47.32, S S=6.60)$ ve 60-75 yaş aras 30 yaşl1 bireylerden (Ort. $=69.97, S S=6.16$ ) veri toplanmıştır. Katılımcılardan kendilerine sunulan 10 adet toplumsal olay için hatırlama/bilme değerlendirmesi yapmaları istenmiştir. Sonrasında hem sunulan olayın içeriğine ilişkin (SB) hem de olayı haber alma bağlamının hatırlanmasına ilişkin (EB) soruları cevaplamışlardır. Son olarak, hatırlama sırasındaki heyecan düzeylerini belirtmiş ve olayları önem, duygusal yük ve yoğunluk gibi fenomonolojik özellikler açısından değerlendirmişlerdir. Heyecanlanma düzeyi GSR (Galvanic skin response) cihazı ile fizyolojik ölçümler yapılarak da değerlendirilmiştir. Öz-bildirime dayalı heyecanlanma düzeyinin SB süreçlerine kıyasla EB için yüksek olduğu gözlemlenirken, heyecanlanmanın beş fizyolojik gösterge için farklı örüntüler gösterdiği bulunmuştur. Heyecanlanma düzeyi arttıkça $\mathrm{EB}$ ve SB performansları da artmış ve genç bireyler diğer iki yaş grubuna kıyasla daha yüksek heyecanlanma seviyesi ve daha hızlı fizyolojik tepki göstermiş̧lerdir. Fenomonolojik özellikler incelendiğinde ise hatırlanan olaylar, bilinenlere kıyasla daha önemli, duygusal olarak da daha yoğun ve olumsuz olarak değerlendirilmiştir. Ayrıca, heyecanlanma düzeyi arttıkça olayın öneminin, duygu yoğunluğunun ve olumsuzluk derecesinin arttığı görülmüştür. Bulgulara ek olarak, öz-bildirimlerin güvenilirliği ve objektif ölçümlerin önemi tartışılmıştır. Son olarak, bu çalışmadaki bulgular ve sınırlılıklar göz önünde bulundurularak gelecek araştırmalar için öneriler sunulmuştur.

Anahtar Kelimeler: Otobiyografik bellek, semantik bellek, episodik bellek, heyecanlanma ve bellek, toplumsal olaylar ve bellek, flaş bellek 


\section{ABSTRACT}

The major aims of the study were to investigate (1) the potential differences in arousal levels for episodic (EM) and semantic memory (SM) processes regarding public events and the comparison of these differences for different age groups, (2) the consistency of self-report versus objective measures of arousal, and (3) phenomenological characteristics of the events as function of memory type and arousal level. The sample consisted of 32 young adults whose ages ranged between 18 and 25 years $(M=20.60, S D=2.22), 33$ middle-aged adults aged between 40 and 55 years $(M=47.32, S D$ $=6.60)$, and 30 elderly people aged between 60 and 75 years $(M=69.97, S D=6.16)$. Participants were asked to make a remember/know judgment for the 10 public events presented to them. They further answered event-related questions (SM) and questions regarding the context of hearing about the event (EM). Moreover, they reported their arousal level during recall and evaluated each event in terms of phenomenological characteristics such as importance, emotional intensity, and valence. Arousal level was also measured using physiological measurements with the GSR device. Based on self-reports, EM processes were associated with higher arousal levels compared to SM processes whereas the five physiological indicators of arousal displayed different patterns. Both EM and SM performance displayed an increase together with the increasing arousal levels, and young participants displayed higher levels of arousal and faster physiological responses than both middle-aged and elderly adults. When phenomenological characteristics were examined, remembered public events were rated more important, emotionally more intense and more negative than known events. Furthermore, higher arousal levels were associated with higher ratings of emotional intensity, importance and negativity. The reliability of self-reports and the critical role of applying objective measures were discussed together with the findings. Finally, some suggestions were proposed for future research on the basis of the current limitations and results.

Keywords: Autobiographical memory, semantic memory, episodic memory, arousal and memory, public events memories, flashbulb memory

\section{EXTENDED ABSTRACT}

Memory is not a single unitary system; rather it is a multicomponent structure containing independent but interacting systems and subsystems (Gabrieli, 1998; Schacter, 1992; Tulving, 1995). Distinctions between memory systems have been proposed on the basis of different criteria. For example, Atkinson and Shiffrin (1971) distinguished between short-term and long-term memory on the basis of duration whereas Graf and Schacter (1985) distinguished between explicit and implicit memory on the basis of awareness. For the current study, the further categorization of explicit memory system by Tulving (1972) as episodic memory (EM) and semantic memory (SM) has a critical role because the primary goal is to investigate the EM and SM processes in terms of their relation to arousal level. Arousal level was assessed by physiological measures based on the electrodermal activity in addition to the self-reports of participants. Thus, it became possible to investigate the reliability of self-report measures by comparing their consistency with objective measures gathered by technological devices.

\section{Method}

A total of 95 adults from three different age groups participated in the study. The young group $(N=32)$ consisted of university students aged between 18 and 25 years 
$(M=20.60, S D=2.22)$ whereas the middle-aged $(N=33)$ and elderly $(N=30)$ groups were adult volunteers recruited by snowball method and aged between 40-55 and 60-75 years, respectively. They were presented with ten public events and for each event they were required to make a remember/know judgment. For the remembered events, they answered questions regarding the event itself (SM) in addition to the questions about the context of hearing about the event (EM). However, for the events that are known but not remembered, they only answered the event-related questions. Then, they evaluated phenomenological event characteristics of emotional intensity, valence and importance. Finally they reported their arousal level during recall. During this time, physiological indicators of arousal were recorded through their electrodermal activities by using "Shimmer GSR \& Optical Pulse" device (Burns et al., 2010).

\section{Results}

The results indicated that the increase in arousal level was accompanied by an increase in both episodic and semantic recall when examined on the basis of self reports. For physiological measures, the five indicators displayed differential patterns. With aging, physiological measures demonstrated a decrease in the above threshold reactions $(r(1017)=-.175, p<.01)$ whereas self-report arousal displayed an increase $(r(1025)=.073$, $p<.05)$. Results further demonstrated that self-reported arousal level was significantly higher for remembered (EM) public events compared to known (SM) ones $(t(522)=-21.32$, $p<.001)$. For the arousal level based on physiological measures, the results were more complicated as there were five different physiological indicators. Among these five only one of the indicators displayed significant differences between episodic and semantic recall: mean tonic activity $(t(516)=-2.35, p<.05)$. In terms of the link between age and arousal level, with increasing age a decline was observed in physiological measures as expected. For self-reports, however, the results were in the opposite direction indicating an increase with aging. When the consistency between self-reports and GSR measures was analyzed, the results were inconclusive. The major reason behind that outcome is the presence of five different indicators of physiological arousal in GSR data. As a result, some of these five indicators displayed consistency with self-reports but some others did not. Finally, remembered (EM) and known (SM) public events were compared in terms of their phenomenological characteristics. EM were rated as more important, emotionally more intense and more negative than SM. In addition, emotional intensity and importance of the public events increased as the arousal level increased. Emotional valence, however, displayed a decline and become more negative with increasing arousal levels.

\section{Discussion}


The present research investigated the relationship between arousal level and memory processes regarding public events in three different age groups. The major contribution of the current study was using objective measures of arousal using GSR in addition to the typical self-report data. The results revealed that self-reports seemed to have a very consistent pattern and displayed findings in the expected direction in general. In other words, they seemed to be inferences or interpretations on the basis of what participants remembered, whether they remembered or knew the events and their phenomenological ratings. In that respect, having a remember/know judgment for each presented public event might have affected their self-report arousal levels. Physiological arousal, on the other hand, displayed relatively variable results and its consistency with self-reports was also complicated. The main reason behind these findings is the presence of five different physiological indicators of arousal. This made it very difficult to reach conclusions regarding the effects of physiological arousal because the pattern of results was not the same for all the indicators. Future studies aiming to have physiological measures of arousal should take this limitation into account. In conclusion, our findings highlight the importance of using objective measures such as physiological measure in addition to self-reports, which can be biased, hence, questionable in terms of their reliability. And above all, they show that the nature of episodic and semantic remembering does not seem to be the same for public events. 
Bellek bölünmez tek bir sistemden ziyade farklı, bağımsız ama iletişim içinde olan sistemler ve alt sistemler içeren çok bileşenli bir yapıdır (Gabrieli, 1998; Schacter, 1992; Tulving, 1995). Bugüne kadar araştırmacılar değişik kıstaslara dayanarak farklı bellek sistemleri öne sürmüşlerdir. Örneğin, Atkinson ve Shiffrin (1971) depolama süresini baz alarak kısa-süreli (short-term memory) ve uzun süreli bellek (long-term memory) ayr1mı yapmış, Graf ve Schacter (1985) ise bilincin dahil olup olmamasını kriter alarak açık (explicit) ve örtük (implicit) bellek ayrımı yapmıştır. Tulving (1972) açık bellek sistemini kendi içerisinde episodik ve semantik bellek olmak üzere iki farklı sisteme daha ayırmıştır. Bu ayrıma göre episodik bellek (EB) sistemi bir olayı bağlamı ile beraber hatırlamayı içerirken semantik bellek (SB) sistemi genel gerçekler, bilgiler ve kavramları içermektedir. Tulving (1972) tarafından yapılmış olan bu ayrım mevcut araştırma için önem taşımaktadır, çünkü bu çalışmanın temel amaçlarından biri episodik ve semantik bellek süreçlerinin heyecanlanma ile ilişkisini incelemektir.

Episodik ve semantik bellek sistemlerinden farklı olarak, otobiyografik bellek (OB) sistemi bireyin kişisel geçmişini, anılarını içermektedir (Conway, Wang, Hanyu ve Haque, 2005). Otobiyografik belleğin modern kavramsallaştırmaları episodik ve semantik alt bölümlerini içermektedir. Episodik alt bölüm tekrar yaşıyormuş hissine neden olan özgül detayları içerirken, semantik alt bölüm zamanda zihinsel yolculuk hissi olmaksızın sadece kişisel geçmişle ilgili genel bilgileri içermektedir (Kopelman, Wilson ve Baddeley, 1989; Piolino, Desgranges ve Eustache, 2009; Tulving, Schacter, McLachlan ve Moscovitch, 1988). Bu alt bölümler arasındaki ayrımın altını çizmek önemlidir, çünkü OB sadece episodik değildir. Episodik detaylar olmadan da favori renginiz veya ilkokulunuzun ismi gibi otobiyografik gerçekleri veya semantik bilgileri hatırlamak mümkündür (Conway ve Pleydell-Pearce, 2000; Tulving, ve ark., 1988). Prefrontal bölgelerin ve hipokampüsün episodik ve semantik otobiyografik detayları hatırlamadaki farklı rolünü gösteren araştırmalar bu kavramsallaştırmayı desteklemektedir (Lee, Robbins ve Owen, 2000; Maguire, 2001; Maguire ve Frith, 2003).

Episodik ve semantik bellek sistemlerinin kendi içinde de bilişsel süreçlere dair birtakım ayrımlar öne sürülmüştür. Örneğin, Tulving (1995) episodik bellekte hatırlama (remembering) ve bilme (knowing) süreçleri arasındaki ayrıma dikkat çekmiştir. Bu ayrıma göre hatırlamak, geçmişte olan bir olayın yer ve zamana dair detaylarıyla bilinçli ve aktif bir şekilde anımsanması iken; bilmek, geçmişte olan bir olaya dair episodik detayları hatırlamadan sadece aşinalık hissinin duyulmasıdır. Bu ayrıma bir örnek vermek 
gerekirse, bir kişi kardeşinin ne zaman doğduğunu bilebilir (semantik); fakat bu, o kişinin bu olayı hatırladığı (episodik) anlamına gelmez. Benzer bir hatırlama/bilme fark1 toplumsal olaylar için de olasıdır. Örneğin, bir kişi 12 Eylül darbesini veya New York’taki 11 Eylül terörist saldırılarını biliyor olabilir, fakat bu olayları bilinçli ve aktif bir şekilde hatırlamıyor olabilir. Bu ayrım OB üzerine öne sürülmüş olan episodik ve semantik alt bölümleri için de geçerlidir.

Toplumsal olaylara dair bellek süreçleri genellikle flaş bellek çalışmaları kapsamında araştırılmış ve beklenmedik toplumsal olayların diğer anıların hatırlanmasından farklı olup olmadığına ve aradan geçen zamanla beraber tutarlı bir şekilde detaylı olarak hatırlanıp hatırlanmadığına odaklanmıştır (Brown ve Kulik, 1977; Winograd ve Killinger, 1983). Bu noktada Brown ve Kulik (1977) heyecanlanmanın da anının kalıcılığ 1 ile olay özelliklerinin (örn., duygusal yoğunluk, duygu yükü, önem) farklılaşmasında önemli bir payı olabileceğini savunmuştur. Bir başka ifadeyle, heyecanlanmanın duygusal uyarım düzeyini arttırarak flaş anıların bellek sisteminde temsilini etkileyebileceğini öne sürmüşlerdir. Son zamanlarda yapılan bazı çalışmalar da olayın kişide uyandırdığı heyecan düzeyi ile anının güçlülüğü arasındaki ilişkiye dikkat çekmiştir. Örneğin, kişinin yaşadığı heyecanın ya da duygusal uyarılmanın birçok nörokimyasal değişime yol açtığ belirtilmiştir (McGaugh, 2004). Duygusal uyarılmanın artması ile derideki elektriksel aktivite de artmakta ve kandaki kortizol ile adrenalin hormonlarının oranını yükseltmektedir. Bu fizyolojik değişimlerin de anının daha güçlü veya kalıcı olmasına yol açıyor olabileceği düşünülmüştür (Anderson, Wais ve Gabrieli, 2006; McGaugh, 2004). Mevcut çalışma toplumsal olayların hem episodik hem semantik hatırlanması esnasındaki heyecanlanma düzeyini ölçerek ve bu ölçümleri farklı yaş gruplarında karşılaştırarak alana katkıda bulunmayı hedeflemektedir. Bu bağlamda çalışmanın diğer bir katkısı da birçok flaş bellek çalışmasındaki gibi tek bir toplumsal olayı tek bir yaş grubunda incelemektense (örn., Brown ve Kulik, 1977), 10 tane farklı toplumsal olayın hatırlanmasını genç, orta yaşlı ve ileri yaştaki yetişkinler olmak üzere üç farklı yaş grubunda inceliyor olmasıdır.

Bu araştırmanın alana diğer bir katkısı da öz-değerlendirmelerin güvenilir ve geçerli bir ölçüm yöntemi olup olmadığını objektif fizyolojik ölçümlerle tutarlılığını karşılaştırarak incelemesidir. Öz-değerlendirmeler OB çalışmalarında yaygın olarak kullanılmakta olduğundan (örn., Brown ve Kulik, 1977; Talarico ve Rubin, 2003, 2007) bu yöntemin güvenilirliğini incelemek gelecek araştırmalarda bu yöntemin uygulanması açısından önem taşımaktadır. 
Bellek süreçleri yaşla beraber performans değişikliklerinin gözlemlendiği bir bilişsel süreç olduğundan (örn., Cabeza, 2001; Light, 1991; Raz, 2000; Spilich, 1983) çalışmanın en temel değişkenlerinden birisi katılımcının yaşıdır. Fizyolojik ölçümlerin de tıpkı bilişsel süreçler gibi yaşla beraber değişiklik gösterme olasılığı olduğundan her türlü analizin yaş grupları özelinde de yapılıp raporlanması sonuçların güvenilirliği ve geçerliliği açısından önem taşımaktadır. Bu çalışma toplumsal olaylara dair bellek süreçleri ile heyecanlanma arasındaki ilişkiyi farklı gelişimsel periyodlardaki katılımcılarda ölçerek yaşa bağlı olarak gelişebilecek olası farklılıkları da inceleme imkanı elde etmiştir. Dolayısıyla, bellek süreçleri ve heyecanlanma arasında gözlemlenecek olası bir ilişkinin yaşa bağlı olarak değişip değişmediğinin incelenebilmesi de alana katkı sağlayacaktır.

Otobiyografik bellek araştırmalarında yaygın olarak kullanılan ölçümlerden birisi katılımcıların hatırladıkları olayları duygusal yük, duygusal yoğunluk ve önem gibi birtakım fenomonolojik özellikler açısından değerlendirmesidir. Bu çalışmanın başka bir amacı da bu tarz olay özelliklerini toplumsal olaylar için episodik ve semantik hatırlama süreçleri açısından karşılaştırmaktır. Bu bağlamda mevcut çalışmanın alana katkısı, birden fazla toplumsal olayı üç farklı yaş grubu içerisinde ve farklı hatırlanma tiplerine göre inceleyecek olmasıdır.

\section{Toplumsal Olayların Hatırlanmasında Flaş Bellek Süreçlerinin Önemi}

Toplumsal olaylara dair bellek süreçlerinin incelenmesinde alan yazında flaş belleğin özel bir yeri vardır. Flaş bellek kavramını ilk olarak ortaya atan Brown ve Kulik (1977), beklenmedik, önemli ve duygusal uyarımı yüksek olaylara ilişkin anıların farklı bir mekanizma ile kodlandığını ve hatırlandığını savunmuşlardır. Buna ek olarak, flaş belleği oluşturan anıların çok canlı ve detaylı olarak kaydedildiğini ve aradan yıllar geçse de canlılığını (vividness) koruduğunu ileri sürmüşlerdir. Örneğin, katılımcılara John F. Kennedy'nin öldürüldüğü haberini nerede öğrendikleri, bu sırada yanlarında kimlerin olduğu ve ne yapıyor oldukları gibi sorular sorulduğunda olaydan on yıl sonra bile bu haberi öğrendikleri anın oldukça iyi hatırlandığı gözlemlenmiştir. Yine benzer bir çalışmada, John F. Kennedy'nin öldürüldüğü tarihte altı yaşından büyük olan katılımcıların olayı öğrendikleri ana dair detayları çok net hatırladıkları görülmüştür (Winograd ve Killinger, 1983). Flaş belleği oluşturan anıların bu şekilde canlı ve kalıcı olması, yaşanan olayların niteliği ile açıklanmıştır (Brown ve Kulik, 1977). Başka bir deyişle, beklenmedik toplumsal olayların sıklıkla paylaşılmasının ve dolayısıyla bu bağlamdaki anının tekrarlanmasının bu olayların unutulmaya daha dirençli olmasına yol açtığı savunulmuştur. 
Flaş bellek araştırmaları her ne kadar anının canlı ve detaylı olarak hatırlandığını göstermişse de, son yıllarda yapılan çalışmalar anı ile olay içeriklerini karşılaştırmış ve aslında hatırlanan anının gerçekleşen olayı pek de doğru yansıtmıyor olabileceğini ortaya çıkarmıştır (örn., Talarico ve Rubin, 2007). Flaş anının doğru hatırlandığına dair inanç yüksek olsa da olay detayları ile flaş anı detayları arasında zamanla zayıflayan bir ilişki gözlenmiştir. Örneğin, Talarico ve Rubin (2003)'in çalışmasında kişilere 11 Eylül terör saldırılarını öğrendikleri ana ilişkin sorular sorulmuş ve farklı zamanlarda yapılan değerlendirmelerde tutarsız yanıtlar verildiği görülmüştür. 11 Eylül saldırılarının hatırlanmasıyla ilgili Türkiye örneklemi ile yapılan bir çalışmada da benzer tutarsızlıklar gözlemlenmiştir (Tekcan, Ece, Gülgöz ve Er, 2003). Özetle, flaş bellek anılarını hatırlarken, diğer anılarda olduğu gibi tutarsızlıklar olsa da, kişiler bu anıları daha doğru, net ve ayrıntılı hatırladıklarını düşünmektedirler.

Flaş bellek anılarının öznel güvenilirliği ile tutarlılığg arasında farklılık olması bu olayların kişide yarattığı duygusal uyarımla açıklanmaktadır (Phelps ve Sharot, 2008; Sharot ve Yonelinas, 2008). Anıların öznel güvenilirliği genellikle o olayın kişide bıraktığı etki ile ilgilidir. Dolayısı ile duygusal uyarımı yüksek olan bir olayla ilgili sadece temel birkaç şeyin hatırlanması bile kişinin çok iyi hatırladığını düşünmesine neden olabilmektedir. Flaş bellek anıları hatırlandığında kişi olayı öğrendiği andaki heyecanı tekrar yaşamakta veya hatırlamakta ve kısa yol (heuristic) kullanarak olayı tüm detaylarıyla hatırladığı sonucuna varmaktadır. Bu nedenle, kişiler flaş bellek anılarını yanlış hatırlasalar bile doğru hatırladıklarına dair güvenlerini yüksek olarak değerlendirmektedirler (Kensinger ve Corkin, 2004; Talarico ve Rubin, 2007).

\section{Yaşlanma ve Bellek Süreçleri}

Yaşlanma sıklıkla dikkat kapasitesi (Hasher ve Zacks, 1979) ve bellek süreçleri (Cabeza, 2001; Light, 1991; Raz, 2000; Spilich, 1983) gibi bilişsel alanlarda performansın düşmesiyle ilişkilendirilmektedir. Detaylı incelendiğinde yaşlanma etkileri sadece farklı bellek sistemleri arasında değil, aynı bellek sistemi içerisinde de farklılıklar göstermektedir (Craik ve McDowd, 1987; Grady ve Craik, 2000). Örneğin, yaşlanmayla beraber SB etkilenmezken EB olumsuz etkilenmektedir (McIntyre ve Craik, 1987; Spencer ve Raz, 1995; Zacks, Hasher ve Li, 2000). Episodik bellek sisteminin kendi içerisinde ise hatırlama (recall) performansının tanıma (recognition) performansına kıyasla yaşlanmadan daha büyük ölçüde etkilendiği bulunmuştur (Craik ve McDowd, 1987). 
Otobiyografik belleğin episodik ve semantik alt bölümlerinin de yaşlanmadan farklı etkilendiği öne sürülmüştür (Holland ve Rabbit, 1990; Levine, Svoboda, Hay, Winocur ve Moscovitch, 2002; Piolino, Desgranges, Benali ve Eustache, 2002). Başka bir ifadeyle, episodik detaylar yaşlanmadan olumsuz etkilenirken semantik detayların etkilenmediği görülmüştür (McIntyre ve Craik, 1987; Spencer ve Raz, 1995; Zacks, ve ark., 2000). Buna ek olarak, geçmiş araştırmalar gençlerin otobiyografik anılarının spesifik, yaşlılarınkilerin ise daha genel olduğunu göstermiştir (Addis, Wong, ve Schacter, 2008; Holland ve Rabbit, 1990; Zelinski, Light ve Gilewski, 1984). Farklı ölçüm yöntemleri kullanan birçok araştırma benzer sonuçlar ortaya koymuştur (Borrini, Dall'ora, Della-Sala, Mainelli ve Spinnler, 1989; Cohen ve Faulkner, 1988; Holland ve Rabbit; 1990).

\section{Olay Özellikleri, Heyecanlanma Düzeyi ve Bellek Süreçleri}

Otobiyografik bellek araştırmalarında genellikle hatırlanan olayların duygu yükü, duygu yoğunluğu ve önemi gibi fenomonolojik özellikleri incelenmektedir. Önceki çalışmalar duygu yükü olan materyallerin nötr olanlara kıyasla daha hızlı ve fazla hatırland1ğını göstermektedir (örn., Bradley, Greenwald, Petry ve Lang, 1992; Burke, Heuer ve Reisberg, 1992; Hamann, 2001; Kensinger ve Corkin, 2003; Leigland, Schulz ve Janowsky, 2004; Ochsner, 2000; Ramponi, Handelsman ve Barnard, 2010). Duygunun bellek üzerindeki olumlu etkisi pek çok araştırma ile desteklense de, OB alan yazınında duygu ve bellek arasındaki ilişki nispeten karmaşıktır. Buna göre bazı araştırmalar duyguların anıların genel hatlarının hatırlanmasını arttırırken ayrıntılarının hatırlanmasını zorlaştırdığını göstermektedir (Adolphs, Denburg ve Tranel, 2001; Burke ve ark., 1992; Reisberg ve Heuer, 1992; Wessel ve Merckelbach, 1998). Bunun aksine başka çalışmalar ise yoğun olumsuz duyguların olaylara ilişkin temel detayların hatırlanmasını kolaylaştırırken, çevresel koşullar gibi yan detayların hatırlanmasını zorlaştırdığını öne sürmektedir (Berntsen, 2002). Alan yazındaki bu tarz çelişen bulgular genellikle duygu yükü veya heyecanlanma düzeyi gibi etkenlerle açıklanmaktadır (örn., Kensinger, 2004). Duygu yükü ve heyecanlanma düzeyinin belleğin doğruluğu, sürekliliği ve niteliği üzerindeki etkilerinin ise farklı beyin mekanizmaları tarafından desteklendiği gösterilmiştir. Spesifik olarak, heyecan boyutunun amigdala, duygu yükünün ise kortikal mekanizmalar (örn., orbitofrontal korteks) tarafından işlendiği bulunmuştur (Kensinger, 2004). Ayrıca, duygu yükünün ve heyecan boyutunun anıyı kodlama sürecinde etkili olduğu, bu iki boyutun bellek üzerindeki etkisine bakıldığında ise sadece heyecan boyutunun uzun süreli belleği etkilediği görülmüştür (Bradley ve ark., 1992). Bu nedenle heyecanlanma düzeyinin etki- 
lerinin farklı bellek sistemleri için ayrı ayrı incelenmesi önem taşımaktadır. Bu çalışmada duygu yükü ve heyecanlanma düzeyinin episodik ve semantik hatırlama süreçleri özelinde incelenmesinin önemli nedenini bu bulgular oluşturmaktadır.

\section{Heyecanlanmanın Değerlendirilmesinde Önemli Etkenler: Zaman ve Öznellik}

Olayın yarattığı duygusal uyarım ile flaş bellek arasındaki ilişkinin, olayın üzerinden geçen zamana bağlı olarak da incelenmesi önem taşımaktadır. Fakat, özellikle flaş bellek çalışmalarında olayların gerçekleştiği andaki duygusal uyarımı ölçmek pek mümkün değildir ve genellikle kişilerin geriye dönük öz-bildirimleri baz alınmaktadır (örn., Brown ve Kulik, 1977). Bu yöntemde oluşabilecek sorunlardan biri, duygusal uyarım ya da heyecanlanma düzeyini değerlendirirken kişilerin öznel yorum yapmaları ihtimalidir. Örneğin, iki ayrı bireyin heyecan düzeyine verdikleri öznel değerlendirme puanları aynı olsa bile, bu puana karşılık gelen fizyolojik uyarım düzeyi aynı olmayabilir. Fizyolojik uyarılma düzeyi ise, bireylerin eşik değerleri başta olmak üzere, yaş ve cinsiyet gibi temel değişkenlerden etkilenebilmektedir (Bradley, Codispoti, Sabatinelli, Cuthbert ve Lang, 2001; Gavazzeni, Wiens, ve Fischer, 2008). Bu nedenle, heyecanlanma düzeyinin farklı yaş gruplarında hem öz-bildirim (öznel) hem fizyolojik (objektif) ölçümler bazında belirlenmesinin ve incelenmesinin bulguların güvenilirliğini arttıracağı ve alana katkı sağlayacağı düşünülmektedir.

Duygusal uyarımı fizyolojik yöntemlerle ölçen geçmiş araştırmalar derideki elektriksel aktivitenin duygusal uyarıma bağlı olarak değişim gösterdiğini tespit etmiştir (Fischer ve ark., 2010; Keil ve Freund, 2009; Khalfa, Peretz, Jean-Pierre ve Manon, 2002). Çalışma prensibinden kısaca bahsetmek gerekirse, derideki elektriksel aktivite değişimi sol bileğe yerleştirilen elektrotlardan alınan sinyallerle ölçülmektedir. Bu yöntemin özellikle tercih edilmesinin nedenlerinden biri kolay uygulanmasına ek olarak sempatik sinir sistemindeki değişimlere olan duyarlılığının belirgin olmasıdır. Alan yazına bakıldığında, duygusal uyarımın anının kalıcılığı ve özellikleri üzerindeki etkisi fizyolojik aktivitenin ölçümüyle de gösterilmiştir (Daselaar, Rice, Greenberg, Cabeza, LaBar ve Rubin, 2008; Greenberg, Rice, Cooper, Cabeza, Rubin ve LaBar, 2005; Markowitsch ve ark., 2000; Rugg, Johnson, Park ve Uncapher, 2008). Ancak bu çalışmaların yöntemlerindeki farklılıklar ortak bir sonuca varmayı zorlaştırmaktadır. Örneğin, kimi çalışmada duygusal uyarım düzeyi farklı olan uyarıcılar kullanılmış ve hatırlamada gözlemlenen farklar bu uyarım düzeyi farklılıklarının değişik mekanizmalarla kaydediliyor olmasına bağlanmıştır (Rugg ve ark., 2008). Hatırlama esnasındaki duygusal uya- 
rımın OB üzerindeki etkisine dair başka bir açıklama ise, duygusal uyarımla beraber artan amigdala aktivitesinin bellek mekanizmalarında temel rol oynayan hipokampüsü uyarması ve bunun da anıların geri getirilmesini arttırması şeklindedir (Daselaar ve ark., 2008; Markowitsch ve ark., 2000).

Heyecanlanma ve hatırlama bağlamında OB sıkça çalışılmış olsa da toplumsal olaylara ilişkin bulgular nispeten sınırlıdır. Bunun başlıca sebeplerinden biri olayın yaşand1ğ1 andaki heyecanlanmanın doğrudan ölçülmesinin pek mümkün olmamasıdır. Bu noktada geriye dönük öz-bildirimler OB alan yazınında sıkça kullanılmakta ve olayın hatırlanması sırasındaki heyecan ve duygu yoğunluğuna dair bilgi vermektedir. Bu çalışmada, heyecanlanma düzeyinin öz-bildirime ek olarak fizyolojik ölçümlerle de belirlenmesinin öznel yorumların değerlendirilmesinde ve güvenilirliğinin incelenmesinde önemli rol oynayacağı düşünülmektedir. Hatırlama çerçevesinde ise, bilinen (SB) toplumsal olaylara dair heyecanlanma düzeyinin, hatırlanan (EB) olaylara dair heyecanlanma düzeyiyle karşılaştırılması hedeflenmektedir.

Geçmiş çalışmalar heyecanlanmanın olayın ana detaylarının hatırlanmasını güçlendirirken daha önemsiz yan detaylarının hatırlanmasına neden olduğuna dair bulgular gösterse de, bu tünel etkisi daha çok olumsuz olaylarda kodlamaya ilişkin yanlılıkları açıklamaktadır (Berntsen, 2002). Daha da önemlisi, tünel etkisini inceleyen çalışmalarda EB detaylarından çok SB detaylarına odaklanılmış, ana ve yan SB detayların hatırlanmasında heyecanlanmanın rolü incelenmiştir (MacKay ve Ahmetzanov, 2005; Talarico, Berntsen ve Rubin, 2009). Bu çalışmada ise olaylara ilişkin ana ve yan detaylar ayrılmamakta ve SB detayları bir bütün olarak değerlendirilmektedir. Bu doğrultuda hatırlama esnasındaki heyecanlanmanın artması ile hem EB hem SB detaylarının artacağı öngörülmektedir. Ancak bu örüntünün yaş grupları arasında gösterebileceği olası farklılıkları incelemek amacıyla keşif niteliğinde incelemeler de yapılacaktır. Dolayısıyla gözlemlenen örüntünün yaş grupları arasında farklılık gösterip göstermeyeceğine dair net bir beklenti bulunmamaktadır. Bu noktadan hareketle, Hipotez 1 aşağıdaki şekilde oluşturulmuştur:

H1: Öz-bildirime ve fizyolojik ölçümlere dayalı heyecanlanma düzeyi arttıkça a) hatırlanan episodik (EB) detaylar ve b) olay içeriğine ilişkin (SB) doğru cevap sayısı artı̧̧ gösterecektir.

Geçmiş araştırmalar kişilerin beklenmedik toplumsal olaylara dair öznel güvenilirliklerinin ve tutarlılıklarının düşük olduğunu ve yanlış hatırlasalar bile doğru hatırladık- 
larına dair olan inançlarının yüksek olduğunu göstermektedir (Kensinger ve Corkin, 2004; Talarico ve Rubin, 2007). Bu tutarsızlıklar ve hatırlamanın doğruluğuna dair yanılgılar heyecanlanma düzeyiyle açıklanmaktadır. Ayrıca, episodik olarak hatırlanan olayların yer ve zamana dair detaylarıyla bilinçli ve aktif bir şekilde hatırlanmasının semantik olarak bilinen olaylara özgü aşinalık hissine (Tulving, 1995) kıyasla daha fazla duygusal uyarım yarattığı öne sürülmektedir. Bu çalışmada EB ve SB süreçleri arasındaki farkın yaştan bağımsız olduğu düşünülmektedir. Başka bir deyişle, kişilerin bir olayı episodik hatırlamalarının yaşlarından bağımsız olarak semantik hatırlamaya kıyasla daha fazla heyecan yaratacağı öne sürülmektedir. Bu nedenle, Hipotez 2 aşağıdaki şekilde oluşturulmuştur:

H2: Hatırlanan (EB) olaylara ilişkin a) öz-bildirimlerle ve b) fizyolojik yöntemlerle ölçülen heyecanlanma düzeyleri bilinen (SB) olaylarınkine kıyasla daha yüksek olacaktır. Bu örüntü c) yaş grupları ayrı ayrı incelendiğinde de aynı olacaktır.

Bellek süreçleri kapsamında kişilerin heyecanlanma düzeylerini öz-değerlendirmelere ve fizyolojik ölçümlere dayanarak karşılaştıran geçmiş bir çalışma bulunmamaktadır. Bu nedenle bu karşılaştırmaya dair beklenti tamamen araştırmacıların öngörüsüdür ve geçmiş bir bulguya dayanmamaktadır. Bu çalışmada kişilerin kendi heyecanlanma düzeylerini yaklaşık olarak doğru bir şekilde tahmin edebilecekleri öngörüldüğünden Hipotez 3 aşağıdaki şekilde oluşturulmuştur.

H3: Katılımcıların kendi öz-bildirimlerine dayanan heyecanlanma düzeyleri fizyolojik yöntemlerle ölçülen heyecanlanma düzeyleriyle tutarlılık gösterecektir; biri öznel biri objektif olmak üzere iki farklı yöntemle ölçülmüş olan heyecanlanma seviyesi arasında anlamlı düzeyde pozitif korelasyon gözlemlenecektir.

H1 için de belirtildiği üzere Tulving (1995) episodik hatırlamanın sadece bilmeye kıyasla farklı olduğunu, episodik hatırlamaya bir çeşit zamanda yolculuk hissinin eşlik ettiğini vurgulamaktadır. Hatırlama ve bilme arasındaki bu farkın hatırlanan ve bilinen olayların özelliklerine yansıması olması da muhtemeldir. Bu sebeple hatırlanan ve bilinen toplumsal olayların fenomonolojik özelliklerinin farklılık göstermesi beklenmektedir. Detaylandırmak gerekirse, heyecanlanma düzeyi arttıkça duygu yoğunluğu ile kişi ve toplum için öneminin de artacağ1, duygu yükünün ise daha negatif olacağı düşünülmektedir. Bu doğrultuda aşağıdaki hipotez oluşturulmuştur: 
H4: Bilinen (SB) ve hatırlanan (EB) toplumsal olaylar fenomonolojik özellikleri aç1sından karşılaştırıldığında a) hatırlanan olaylar bilenen olaylara kıyasla duygu yoğunluğu ile kişi ve toplum için önemi açısından daha yüksek, duygu yükü bakımından ise daha negatif olacaktır ve b) olayların fenomonolojik özelliklerin hem fizyolojik hem öz-bildirime dayalı heyecanlanma düzeyleriyle anlamlı düzeyde ilişkili olduğu görülecektir.

\section{YÖNTEM}

\section{Katılımcılar}

Örneklem grubu genç, orta ve ileri yaş olmak üzere üç farklı yaş grubundan oluşmaktadır. Yaş grupları belirlenirken gelişim psikolojisi alan yazınında kabul gören orta yaş ve ileri yaş dönemleri ve bu iki yaş grubundan veri toplamış olan sınırlı sayıdaki otobiyografik bellek çalışmalarında kullanılan yaş aralıkları göz önünde bulundurulmuştur (Demiray ve Bluck, 2011; Dixon, De Frias ve Maitland, 2001; Multhaup ve ark., 2005). Bunun yanında yaşam dönemleri ve toplumsal olayların etki dönemlerini ayrıştırabilmek amacıyla yıllar arasında belirgin aralıklar bırakılmıştır. Sonuç olarak araştırmada kullanılan yaş aralıkları genç grup için 18-25 (Ort. $=20.60, S S=2.22)$, orta yaş için 40-55 (Ort. $=47.32, S S=6.60)$ ve ileri yaş grubu için 60-75'tir (Ort. $=69.97, S S=$ 6.16). Genç yaş grubunda 32, orta yaş grubunda 33, ileri yaş grubunda ise 30 olmak üzere araştırmaya toplam 95 yetişkin (\% 64 kadın) katılmıştır. Genç yaş grubu üniversite öğrencilerinden, orta ve ileri yaş grupları ise kartopu yöntemiyle ulaşılan sağlıklı ve gönüllü katılımcılardan oluşmaktadır. İleri yaş grubu katılımcılarının bilişsel işlevlerinin taranması amacıyla Standardize Mini Mental Test'inin (SMMT) Türkçe uyarlaması (Güngen, Ertan, Eker, Yaşar ve Engin, 2002) uygulanmıştır. Bu tarama testi sonucunda araştırmadan çıkarılan ileri yaş katılımcı olmamıştır.

\section{Veri Toplama Araçları}

Olay Listesi ve Olaylara İlişkin Sorular. Her yaş grubundaki katılımcılara doğdukları yıldan 2013'e kadarki zaman aralığında olmuş toplam 10 adet toplumsal olay sorulmuştur (örn., Barış Manço’nun ölümü, Orhan Pamuk’un Nobel Edebiyat Ödülü’nü alması vb.). Araştırmada kullanılmış olan tüm olayların listesi Ek-1'de sunulmuştur. Gazete arşivlerinden taranarak her y1l için toplam beş olay seçilmiş, daha sonra seçilen olaylar lisans ve yüksek lisans öğrencilerinden oluşan toplam 28 kişilik bir araştırma grubu tarafından değerlendirilmiştir. Araştırma grubundaki her bir kişi gazete arşivlerin- 
den seçilmiş olan toplumsal olayları, önem ve araştırmaya uygunluk açısından beş puan üzerinden değerlendirmiş ve her yıl için toplamda en yüksek puanı alan olay belirlenmiştir.

$\mathrm{Bu}$ araştırmada her yaş grubundaki katılımcılara sunulan toplam olay sayısının 10 adet ile sınırlandırılmasının nedeni her yaş grubundan beş katılımcı olacak şekilde toplam 15 kişi ile yapılan pilot çalışmada elde edilen verilerin, deri yüzeyinden elde edilen elektriksel ölçümlerin 20 dakikayı aşan sürelerde sağlıklı sonuç vermediğini ve katılımcıların tepki düzeylerinin peş peşe gelen benzer nitelikte sorulardan dolayı temel düzeye düşmekte olduğunu göstermiş olmasıdır. Bu bağlamda alanda yapılan çalışmalara da bakıldığında, tekrar etmeyen bilişsel ya da davranışsal testlerle ilişkili olarak deri yüzeyinden fizyolojik ölçümlerde deney oturumunun 25 dakikayı aşmadığ (örn., Esen, Celebi, Ertekin ve Colakoglu, 1997; Leiner, Fahr ve Früh, 2012; Vecchiato ve ark., 2010). Bu nedenle fizyolojik ölçümlerin güvenirliğini korumak adına, pilot çalışma gözlemlerine dayanarak toplam olay sayısının 10 adet ile sınırlanması uygun görülmüştür. Her yaş grubu için 10 olay seçkisiz olarak belirlenmiş ve ilgili yaş grubundaki en genç kişinin doğum yılı ile araştırma yılı arasında dengeli bir dağılım olmasına dikkat edilmiştir. Başka bir deyişle, katılımcıya sunulan 10 olayın çoğunun çocukluk dönemine ya da son 3 yılına gibi belirli bir döneme yı̆̆ılmamasına özen gösterilmiştir. Ayrıca yaş grupları arasındaki karşılaştırmaların anlamlı olabilmesi için örtüşen yıllardaki olaylar aynı tutulmuştur. Araştırmada kullanılmış olan tüm toplumsal olayların her yaş grubu için ayrı olacak şekilde Ek-1'de gösterilmiştir.

Son olarak, yine gazete haberlerindeki bilgiler göz önünde bulundurularak seçilen her toplumsal olay için olay içeriğine ilişkin (SB) beş soru hazırlanmıştır. Buna ek olarak, olayın haber alındığı anın hatırlanmasına dair (EB) iki, olayın fenomonolojik özelliklerine dair ise beş adet olmak üzere yedi soru hazırlanmıştır. Semantik sorulara ek olarak hazırlanmış bu yedi soru şunları içermektedir: (1) haberin kaynağı, (2) haber alındığı sırada nerede olunduğu, (3) olayın haber alındığı sıradaki (kodlama) duygu yoğunluğu, (4) olayın hatırlanması esnasındaki (hatırlama) duygu yoğunluğu, (5) olayın toplum için önemi, (6) olayın kişi için önemi ve (7) olayın (olumlu-olumsuz) duygu yükü. Üçüncü ve dördüncü sorulardaki iki değişken bulgularda ve tablolarda sırasıyla duygu yoğunluğu (k) ve duygu yoğunluğu (h) şeklinde belirtilmiştir. Son olarak, fizyolojik ölçümlerle karşılaştırabilmek amacıyla katılımcılara olayın hatırlanması esnasındaki heyecanlanma düzeyleri sorulmuştur. 
Standardize Mini Mental Test (SMMT). Orijinali Folstein, Folstein ve McHugh (1975) tarafından yayınlanmış olan Mini Mental Test'in standardize versiyonu 1997 y1lında Molloy ve Standish tarafından yapılmıştır. Türkçe uyarlaması ise Güngen ve arkadaşları tarafından 2002 yılında yapılmıştır. Bu test yaşlılarda kayıt hafızası, oryantasyon, dikkat ve matematik becerisi, hatırlama ve dil olmak üzere beş faklı alanı değerlendirmektedir ve Türkiye'deki yaşlı örneklemde hafif demansı tanımada yüksek duyarlılığa sahip olduğu bulgulanmıştır (Güngen ve ark., 2002). Testten alınabilecek toplam puan 30, kişilerin kognitif bozukluğu olup olmadığına karar vermek için kritik puan ise 24 'tür.

Bellek Soruları. Olayların içeriğine ilişkin sorulardan önce, araştırmacı katılımcılara bilme ve hatırlama arasındaki farkı aşağıdaki yönergeyi kullanarak açıklamıştır.

“Bazen, bir olayı biliyor olmamız onu hatırladı̆̆ımız anlamına gelmez. Örneğin, ben Kemal Sunal'ın öldüğünü biliyorum ama öldüğünü nasıl öğrendiğimi hatırlamıyorum. Dediğim gibi bir olayı biliyor olmamı illa ki hatırladığımı anlamına gelmeyebilir. Bu nedenle sizden ricam, bir olayı bildiğinizi söylediğinizde bu olayı bilmenin ötesinde hatırlayıp hatırlamadı̆̆ınızı düşünerek bana söylemeniz."

Ardından her bir olay katılımcıya verilerek öncelikle olayı bilip bilmediği, biliyor ise de hatırlayıp hatırlamadığı sorulmuştur. Olayı bildiğini ama hatırlamadığını belirten katılımcılara sadece olayın içeriğine ilişkin SB soruları sorulmuş, olayı bildiğini ve hatırladığını belirten katılımcılara ise SB sorularına ek olarak EB soruları sunulmuştur. Araştırmada kullanılan olayların içeriğine (SB) ve hatırlanmasına ilişkin (EB) bellek soruları örnek bir olay bağlamında Ek-2'de verilmiştir.

Fizyolojik Ölçümler. Heyecanlanmanın fizyolojik boyutu Shimmer GSR \& Optical Pulse (Burns ve ark., 2010) taşınabilir cihazları ile ölçülmüştür. İşaret ve orta parmağın ikinci boğumuna takılan elektrotlardan elde edilen sinyaller bluetooth aracıl1ğıyla bilgisayara gönderilmiştir. Bilgiler, bilgisayarda bu sinyalleri işlemek için kullanılan bir program aracılığıyla kayıt edilmiştir. Ayrıca gelen sinyaller sürekli olduğundan, ölçümler SB ve EB soru bölümlerine ayrılmıştır. Bu ayrımı yapmak amacıyla MatLab kullanılmıştır. MatLab’ta deri iletkenliği verisi ile eşzamanlı çalışarak soruların başlama ve bitiş anlarını işaretleyebilen bir program yazılmıştır. Böylece gelen sinyallerin hangi sorular sırasında alınan ölçümler olduğu belirlenebilmiş ve ona göre değerlendirilebilmiştir. 


\section{Veri Analizi}

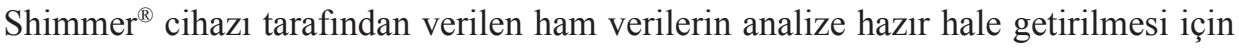
MatLab üzerinde yazılmış bir program olan Ledalab 3.4.6 (Leipzig ElectroDermal Activity Lab) kullanılmıştır. Analizlerde Lim ve arkadaşları (1997) tarafından önerilmiş olan Ayrık Ayrıştırma Analizi (Discrete Decomposition Analysis) yöntemi ve ardından önerilen optimizasyon yöntemleri uygulanmıştır. Bu yöntem deri iletkenliği verisini tonik (uyarıcı etki ile ilgili olan) ve ayrık fazik (safhalara ilişkin olan) parçalarına ayrıştırmaktadır. Bu şekilde katılımcıların SB ve EB soruları sırasındaki genel heyecanlanma düzeylerine dair veriler elde edilmiş ve SPSS $^{\circledR}$ istatistik analiz paketi kullanılarak analiz yapılabilecek hale getirilmiştir. Bu veriler daha sonra sorulan sorulardan alınan verilerle birleştirilmiştir.

Veri analizinde kişilerin sözlü olarak verdikleri yanıtlarla birlikte deri iletkenliği tepkilerinin dönüştürüldüğü Ayrık Ayrıştırma Analizi ile elde edilen beş tür ölçüm verisi incelenmiştir. Heyecanlanma sırasında deri iletkenliğinde olan değişikliği farklı biçimleriyle ele alan bu beş gösterge verilen zaman aralığında eşik üzerinde olan tepkilerin sayısı (EÜTepSay), ilk eşik üzeri tepkinin ortaya çıkma süresi (EÜTepSür), verilen zaman aralığında eşik üzerinde olan deri iletkenliği tepkilerinin toplam yüksekliği (EÜTepTopYük), verilen zaman aralığında eşik üzerinde olan deri iletkenliği tepkilerinin toplam yaygınlık alanı (EÜTopYayAl) ve ortalama tonik (uyarıcı etkiye yönelik olan) aktivitedir (OrtTonAk). Burada belirtilen eşik değeri, olaylar sorulmaya başlamadan önce alınan iki dakikalık dinlenme süresindeki deri iletkenliğine karşılık gelmektedir ve katılımcıya özgü bir değerdir.

Semantik bellek soruları cevapların doğruluğuna göre 0-1-2 şeklinde kodlanmış ve beş soru üzerinden toplam puan baz alınarak ilgili analizler yapılmıştır. Örneğin, cevaplar katılımcı soruyu boş bırakmışsa, yanlış cevaplamışsa veya "bilmiyorum/hatırlamıyorum" şeklinde cevap vermişse 0 , çok genel veya tahmin niteliğinde kısa bir cevap vermişse 1, doğru cevap vermişse 2 olarak kodlanmıştır. Şunu belirtmek gerekir ki, episodik bilgiler katılımcıya özgü olduğu ve araştırmacı tarafından doğruluğunun bilinmesi mümkün olmadı̆̆ 1 için verilen cevaplar içeriğe bakılarak detay miktarına göre puanlanmıştır. Detaylı incelendiğinde ise EB sorularına verilen cevaplarda varyansın çok düşük olduğu ve SB soruları gibi 0-1-2 şeklinde kodlanmasının mümkün olmadığı görülmüştür. Bu nedenle, EB soruları 0-1 olarak kodlanmış ve analizler yine toplam puan üzerinden yapıllmıştır. Eğer soru boş bırakılmışsa ya da "bilmiyorum" veya "hatırlamıyorum" 
şeklinde cevaplanmışsa 0, belirli bir cevap sunulmuşsa (örn., "evdeydim”, “televizyondan duydum") 1 olarak puanlanmıştır. Heyecanlanma düzeyi, duygu yoğunluğu (kodlama ve hatırlama), olayın önemi (toplum ve kişi için) değişkenleri 5'li Likert tipi ölçümle puanlanmıştır. Son olarak, duygu yükü değişkeni yine Likert tipi ölçek ile -2 ile +2 arasında değişen puanlarla ( $-2=$ Çok olumsuz, -1 = Olumsuz, $0=$ Ne olumlu ne olumsuz, $+1=$ Olumlu ve $+2=$ Çok olumlu) ölçülmüştür.

\section{İşlem}

Araştırmada kullanılacak ölçümlerin yapılabilmesi için Koç Üniversitesi İnsan Araştırmaları Etik Kurulu'ndan onay alınmıştır. Öncelikle tüm katılımcılardan bilgilendirilmiş onam formunu okumaları ve onayladıkları takdirde araştırmaya başlamaları talep edilmiştir. Bu sırada soruları varsa araştırmacıya yöneltebilecekleri ve diledikleri zaman çalışmadan çekilebilecekleri konusunda bilgilendirilmişlerdir. Daha sonra katılımcıların parmaklarına heyecan ölçme amacıyla kullanılan sensör takılmış ve sensörün bilgisayar ile olan iletişimi sağlandıktan sonra katılımcılardan doğum tarihi, cinsiyet ve eğitim düzeyi bilgileri alınmıştır. Olayların sunum sırası seçkisiz şekilde ayarlanmıştır. Araştırma sırasında kişilerin ses kaydı alınmış ve bu kayıtlar sorularla deri yüzeyinden elde edilen elektriksel ölçüm cihazı arasındaki senkronizasyonun bir sağlaması olarak kullanılmıştır. Bu sağlama, ses kaydı ile veri grafiğini karşılaştırarak ve katılımcının hatırlayıp raporlama yaptığı esnadaki ölçümleri inceleyerek yapılmıştır.

\section{BULGULAR}

\section{Heyecanlanma Düzeyi ve EB Performansı (H1a) ile SB Performansı (H1b) Arasındaki İlișki}

Toplam EB detay puanlarının öz-bildirim ve fizyolojik ölçümlere dayanan heyecanlanma göstergeleriyle korelasyonları hem tüm örneklem grubu için hem de her yaş grubu için birlikte analiz edilmiştir. Öz-bildirime dayalı heyecan puanları tüm analizlerde toplam EB detayı ile anlamlı düzeyde pozitif korelasyon göstermiştir. İlgili istatistiksel değerler Tablo 1'de sunulmuştur.

Tablo 1'de de görüldüğü üzere her yaş grubunda katılımcıların kendi belirttikleri heyecan düzeyleri arttıkça hatırlamış oldukları EB detay miktarı da beklenildiği gibi artış göstermiştir. Fizyolojik ölçümlere dayanan heyecanlanma beş farkl1 gösterge ile ölçüldügünnden bulgular daha farklı örüntüler göstermiştir. Genç yetişkinlerin EB detay hatırlamaları ve fizyolojik heyecanlanma düzeyleri incelendiğinde sadece EÜTepSay 
Tablo 1. Farklı Yaş Gruplarında EB Detay Puanları ile SB Doğru Puanlarının Öz-bildirime ve Fizyolojik Ölçüme Dayalı Heyecanlanma ile İlişkisi

\begin{tabular}{|c|c|c|c|c|c|c|c|}
\hline Değişken & Episodik & Semantik & Öz-değ. & EÜTepSay & EÜTepSür & EÜTopTepYük & EÜTopYayAl \\
\hline \multicolumn{8}{|l|}{ Semantik doğru } \\
\hline Tüm örneklem & $.66^{* *}$ & & & & & & \\
\hline Genç & $.57 * *$ & & & & & & \\
\hline Orta & $.74 * *$ & & & & & & \\
\hline İleri & $.66^{* *}$ & & & & & & \\
\hline \multicolumn{8}{|l|}{ Öz-bildirim } \\
\hline Tüm örneklem & $.88^{* *}$ & $.66^{* *}$ & & & & & \\
\hline Genç & $.87 * *$ & $.59 * *$ & & & & & \\
\hline Orta & $.92 * *$ & $.74 * *$ & & & & & \\
\hline İleri & $.88 * *$ & $.64 * *$ & & & & & \\
\hline \multicolumn{8}{|l|}{ EÜTepSay } \\
\hline Tüm örneklem & .02 & $-.07 *$ & -.03 & & & & \\
\hline Genç & $.20 * *$ & $.13^{*}$ & $.22 * *$ & & & & \\
\hline Orta & $-.21 * *$ & $-.21 * *$ & $-.14 *$ & & & & \\
\hline İleri & -.01 & $-.17 * *$ & -.09 & & & & \\
\hline \multicolumn{8}{|l|}{ EÜTepSür } \\
\hline Tüm örneklem & -.05 & .04 & -.03 & $-.70 * *$ & & & \\
\hline Genç & -.11 & -.09 & $-.12 *$ & $-.81 * *$ & & & \\
\hline Orta & -.04 & .03 & -.05 & $-.68 * *$ & & & \\
\hline İleri & .07 & $.21 * *$ & .10 & $-.66^{* *}$ & & & \\
\hline \multicolumn{8}{|l|}{ EÜTopTepYük } \\
\hline Tüm örneklem & $.13 * *$ & .04 & $.08^{*}$ & $.54 * *$ & $-.26 * *$ & & \\
\hline Genç & .10 & -.02 & $.13^{*}$ & $.55 * *$ & $-.33 * *$ & & \\
\hline Orta & .07 & .09 & $.13^{*}$ & $.58 * *$ & $-.26 * *$ & & \\
\hline İleri & $.23 * *$ & .02 & $.15^{*}$ & $.58 * *$ & $-.25 * *$ & & \\
\hline \multicolumn{8}{|l|}{ EÜTopYayAl } \\
\hline Tüm örneklem & .03 & -.04 & .03 & $.40 * *$ & $-.16^{* *}$ & $.80 * *$ & \\
\hline Genç & .02 & -.10 & .05 & $.41 * *$ & $-.22 * *$ & $.88^{* *}$ & \\
\hline Orta & $-.24 * *$ & $-.16 * *$ & $-.19 * *$ & $.59 * *$ & $-.29 * *$ & $.50 * *$ & \\
\hline İleri & $.20 * *$ & -.05 & $.24 * *$ & $.20 *$ & .07 & $.36^{* *}$ & \\
\hline \multicolumn{8}{|l|}{ OrtTonAk } \\
\hline Tüm örneklem & -.03 & -.00 & -.05 & $-.28 * *$ & $.22 * *$ & $-.74 * *$ & $-.82 * *$ \\
\hline Genç & .05 & .11 & -.01 & $-.25 * *$ & $.30 * *$ & $-.76^{* *}$ & $-.87 * *$ \\
\hline Orta & .11 & .06 & .06 & $-.53 * *$ & $.34 * *$ & $-.59 * *$ & $-.79 * *$ \\
\hline İleri & $-.30 * *$ & $-.23 * *$ & $-.36 * *$ & .06 & -.05 & $-.29 * *$ & $-.49 * *$ \\
\hline
\end{tabular}

Not: ${ }^{*} p<.05 ; * * p<.01$,

EÜTepSay: Verilen zaman aralığında eșik üzerinde olan tepkilerin sayısı, EÜTepSür: İlk eșik üzeri tepkinin ortaya çıma süresi,

EÜTepTopYük: Verilen zaman aralığında eşik üzerinde olan deri iletkenliği tepkilerinin toplam yüksekliği, EÜTopYayAl: Verilen zaman aralığında eșik üzerinde olan deri iletkenliği tepkilerinin toplam yaygınlık alanı, OrtTonAk: Ortalama tonik (uyarıcı etkiye yönelik olan) aktivite, SB: Semantik bellek, EB: Episodik bellek 
değiş̧eni ile pozitif korelasyon gözlemlenmiştir. Orta yaşl yetişkinlerde ise EB detayı EÜTepSay ve EÜTopYayAl ile negatif korelasyon göstermiştir. Dolayısıyla, EB detayları daha fazla hatırlayan orta yaşlı yetişkinlerin eşik üstü tepki sayısının ve toplam yaygınlık alanının daha az olduğu görülmüştür. Son olarak, ileri yaş grubunda EB detay miktarı EÜTopTepYük ve EÜTopYayAl ile pozitif, OrtTonAk değişkeni ile ise negatif korelasyon göstermiştir (Bkz. Tablo 1). Dolayısıyla, eşik üstü tepki sayısı ve toplam yaygınlık alanı yüksek, ortalama tonik aktivitesi düşük olan ileri yaş yetişkinlerde daha fazla EB detayı hatırlandığı gözlenmiştir. Özetle, fizyolojik heyecanlanmanın beş göstergesi aynı değişkenle farklı ilişkiler göstermiştir. Öz-bildirime dayanan heyecanlanma ise tutarlı bir şekilde her yaş grubunda hatırlanan toplam EB detayı ile pozitif korelasyon göstermiştir. Sonuç olarak, öz-değerlendirmeye dayalı analizler H1a'yı tamamen desteklerken beş farklı göstergeye dayanan fizyolojik ölçümlerin baz alındığı analizler bu hipotezi kısmen desteklemiştir.

Aynı analizler toplam SB doğru puanı için de tekrarlanmıştır. Episodik detaylara benzer şekilde, hatırlanan toplam SB doğru sayısı öz-bildirime dayanan heyecanlanma düzeyiyle tüm yaş gruplarında ve bütün örneklemde pozitif korelasyon göstermiştir (Bkz. Tablo 1). Fizyolojik heyecanlanma düzeyine bakınca, EÜTepSay değişkeni toplam SB doğru puanı ile gençlerde pozitif, orta ve ileri yaş gruplarında ise negatif korelasyon göstermiştir. Tüm örneklem ele alındığında ise SB doğru sayısı sadece EÜTepSay değişkeni ile anlamlı düzeyde negatif korelasyon göstermiş, diğer fizyolojik heyecanlanma değişkenleriyle anlamlı düzeyde bir korelasyon görülmemiştir. Burada dikkat çekici olan sonuç, gençlerin fizyolojik heyecanlanma düzeyi yüksek olduğunda daha iyi SB performansı gösterirken, orta ve ileri yaştaki yetişkinlerin bunun aksine artan heyecanlanma düzeyi ile SB performanslarının düşüyor olmasıdır. Genç grupta diğer fizyolojik heyecanlanma göstergelerine dair anlamlı bir bulgu saptanmamıştır. Orta yaş grubunda ise EÜTopYayAl değişkeni doğru SB puanı ile negatif korelasyon göstermiştir. Başka bir deyişle, orta yaşlı yetişkinler eşik üstü tepkilerinin toplam yaygınlık alanı arttıkça olayların içeriğine dair hatırladıkları doğru semantik bilgi miktarı düşüş göstermiştir. İleri yaş grubu incelendiğinde, EÜTepSür değişkeni toplam doğru SB puanı ile pozitif korelasyon göstermiştir. Dolayısıyla, ileri yaştaki yetişkinlerde ilk eşik üstü tepkinin ortaya çıkma süresi uzadıkça daha çok doğru semantik bilgiyi hatırladıkları görülmüştür. Ayrıca bu yaş grubunda ortalama tonik aktivite artıkça hatırlanan doğru semantik bilgi miktarının azaldığı tespit edilmiştir (Bkz. Tablo 1). Özetle, EB detay analizlerinde olduğu gibi öz-bildi- 
rime dayalı analizler H1b’yi tamamen desteklerken, fizyolojik ölçülere dayalı analizler kısmen desteklemiş, kısmen beklenenin aksi yönde ilişki göstererek çelişmiştir.

Son olarak, EB detay miktarı ile doğru SB puanı arasındaki ilişki incelenmiştir. Hem tüm örneklemde hem yaş grupları birbirinden bağımsız incelendiğinde bu iki değişken birbiriyle anlamlı düzeyde pozitif korelasyon göstermiştir (Bkz. Tablo 1). Daha fazla episodik detay hatırlayan katılımcılar aynı zamanda daha fazla doğru semantik bilgi hatırlamışlardır.

\section{SB ve EB Süreçlerinin Heyecanlanma Açısından Karşılaştırılması (H2)}

Araştırmanın ikinci hipotezini test etmek amacıyla bilinen (SB) olaylara ait heyecanlanma düzeyi ile hatırlanan (EB) olaylara ait heyecanlanma düzeyi hem öz-değerlendirme (H2a) hem fizyolojik ölçümler (H2b) baz alınarak t-test analizleri ile karşılaştırılmıştır. Bulgular katılımcıların öz-bildirime dayalı heyecan düzeylerinde anlamlı farklılıklar gösterirken $(t(522)=-21.32, p<.001)$ fizyolojik heyecanlanma göstergesi olarak kullanılan beş değişkenden (EÜTepSay, EÜTepSür, EÜTopTepYük, EÜTopYayAl ve OrtTo$\mathrm{nAk}$ ) sadece ortalama tonik aktivite düzeyinde anlamlı bir fark ortaya koymuştur $(t(516)$ $=-2.35, p<.05)$. Bu analizlere ait istatistiksel değerler hem tüm örneklem grubu $(\mathrm{H} 2 \mathrm{a}$, $\mathrm{H} 2 \mathrm{~b})$ için hem de her yaş grubu (H2c) için ayrı olacak şekilde Tablo 2'de sunulmuştur.

Tablo 2'de de görüldüğü üzere bulgular öz-bildirime dayalı heyecanlanma düzeyinin EB olayları için SB olaylarına kıyasla anlamlı düzeyde daha yüksek olduğunu göstererek H2a'yı desteklemiştir. Katılımcılar hatırladıkları olaylar için bildikleri olaylara kıyasla hatırlama esnasında daha fazla heyecanlandıklarını ifade etmişlerdir. H2b ise fizyolojik ölçümün beş farklı göstergesi olduğundan ve bu göstergelerden bir tanesi anlamlı düzeyde farklılık gösterdiğinden kısmi olarak desteklenmiştir. Ortalama tonik aktivite düzeyi SB için EB olaylarına kıyasla daha düşüktür. Bu bulgular yaş grupları ayrı ayrı incelendiğinde (H2c) ise sonuçlar orta ve ileri yaş katılımcılar için değişmezken genç yetişkinlerde iki fizyolojik ölçüm değeri EÜTepSay ve EÜTepSür anlamlı farkl1lıklar göstermiştir (Bkz. Tablo 2). Ortalama değerler incelendiğinde ise genç katılımcıların eşik üstü tepki sayısının hatırlanan (EB) olaylar için bilinen (SB) olaylara kıyasla daha yüksek olduğu görülmüştür (Bkz. Tablo 2). Ayrıca, ilk eşik üstü tepkinin ortaya çıkma süresinin SB olaylarına kıyasla EB için daha kısa olduğu bulunmuştur. Başka bir deyişle, genç yetişkinler SB olaylarına kıyasla, EB olaylarına hem daha fazla hem daha hızlı fizyolojik tepki göstermişlerdir. Genç yetişkinlerde gözlemlenen bu ekstra örüntü H2b'ye destek sağlamaktadır. 
Tablo 2. Bilinen (SB) ve Hatırlanan (EB) Toplumsal Olayların Her Yaş Grubunda ve Tüm Örneklemde Karşıllaştırılmasına Ait İstatistik Değerleri

\begin{tabular}{|c|c|c|c|c|c|c|c|c|c|}
\hline \multirow[b]{2}{*}{ Değișken } & \multicolumn{3}{|c|}{ Bilinen (SB) } & \multicolumn{3}{|c|}{ Hatırlanan (EB) } & \multirow[b]{2}{*}{$d f$} & \multirow[b]{2}{*}{$t$} & \multirow[b]{2}{*}{$p$} \\
\hline & $N$ & $X$ & $S S$ & $N$ & $X$ & $S S$ & & & \\
\hline \multicolumn{10}{|l|}{ Öz-bildirim } \\
\hline Tüm örneklem & 107 & .07 & .54 & 417 & 3.07 & 1.42 & 522 & -21.32 & .000 \\
\hline Genç & 70 & .00 & .00 & 162 & 2.52 & 1.22 & 230 & -17.34 & .000 \\
\hline Orta yaşli & 16 & .50 & 1.37 & 99 & 3.85 & 1.29 & 113 & -9.57 & .000 \\
\hline Yaşlı & 21 & .00 & .00 & 156 & 3.13 & 1.47 & 175 & -9.76 & .000 \\
\hline \multicolumn{10}{|l|}{ EÜTepSay } \\
\hline Tüm örneklem & 109 & 2.62 & 2.21 & 409 & 2.96 & 2.09 & 516 & -1.49 & .138 \\
\hline Genç & 66 & 2.61 & 2.25 & 154 & 4.03 & 1.59 & 218 & -5.33 & .000 \\
\hline Orta yaşlı & 22 & 2.09 & 2.37 & 99 & 2.00 & 2.22 & 119 & .17 & .864 \\
\hline Yaşlı & 21 & 3.24 & 1.81 & 156 & 2.53 & 2.01 & 175 & 1.54 & .125 \\
\hline \multicolumn{10}{|l|}{ EÜTepSür } \\
\hline Tüm örneklem & 74 & 1.60 & .62 & 306 & 1.51 & .54 & 378 & 1.3 & .194 \\
\hline Genç & 45 & 1.69 & .67 & 140 & 1.41 & .39 & 183 & 3.44 & .001 \\
\hline Orta yaşlı & 10 & 1.31 & .19 & 51 & 1.59 & .68 & 59 & -1.29 & .204 \\
\hline Yaşlı & 19 & 1.56 & .60 & 115 & 1.60 & .60 & 132 & -.27 & .787 \\
\hline \multicolumn{10}{|l|}{ EÜTopTekYük } \\
\hline Tüm örneklem & 109 & 4.71 & 6.92 & 409 & 3.73 & 5.48 & 516 & 1.57 & .118 \\
\hline Genç & 66 & 6.34 & 8.21 & 154 & 6.81 & 7.22 & 218 & -.42 & .673 \\
\hline Orta yaşlı & 22 & 1.48 & 2.34 & 99 & 1.68 & 2.75 & 119 & -.31 & .756 \\
\hline Yaşlı & 21 & 2.99 & 3.26 & 156 & 2.00 & 2.75 & 175 & 1.51 & .132 \\
\hline \multicolumn{10}{|l|}{ EÜTopYayAl } \\
\hline Tüm örneklem & 109 & 12.05 & 20.86 & 409 & 8.96 & 13.83 & 516 & 1.84 & .066 \\
\hline Genç & 66 & 17.01 & 25.40 & 154 & 14.45 & 16.65 & 218 & .89 & .376 \\
\hline Orta yaşli & 22 & 3.13 & 4.95 & 99 & 3.86 & 5.81 & 119 & -.54 & .588 \\
\hline Yaşlı & 21 & 5.80 & 4.16 & 156 & 6.78 & 12.53 & 175 & -.34 & .723 \\
\hline \multicolumn{10}{|l|}{ OrtTonAk } \\
\hline Tüm örneklem & 109 & -2.97 & 6.17 & 409 & -1.92 & 3.40 & 516 & -2.35 & .019 \\
\hline Genç & 66 & -4.42 & 7.54 & 154 & -2.93 & 4.70 & 218 & -1.77 & .078 \\
\hline Orta yaşlı & 22 & -.48 & 1.43 & 99 & -.52 & 1.61 & 119 & .107 & .915 \\
\hline Yaşlı & 21 & -1.01 & 1.05 & 156 & -1.81 & 2.18 & 175 & 1.649 & .101 \\
\hline
\end{tabular}

EÜTepSay: Verilen zaman aralığında eşik üzerinde olan tepkilerin sayısı, EÜTepSür: İlk eşik üzeri tepkinin ortaya çıkma süresi, EÜTepTopYük: Verilen zaman aralığında eșik üzerinde olan deri iletkenliği tepkilerinin toplam yüksekliği, EÜTopYayAl: Verilen zaman aralığında eşik üzerinde olan deri iletkenliği tepkilerinin toplam yaygınlık alanı. OrtTonAk: Ortalama tonik (uyarıcı etkiye yönelik olan) aktivite, SB: Semantik bellek, EB: Episodik bellek

\section{Öz-bildirime ve Fizyolojik Ölçümlere Dayalı Heyecanlanma Düzeyi Arasındaki İlişki (H3)}

Katılımc1ların öz-bildirimlerine dayanan heyecanlanma düzeyleri ile GSR ölçümüne dayanan fizyolojik ölçümler arasındaki korelasyon incelenmiştir. Tüm örneklem grubunda incelendiğinde, öz-bildirimler beş fizyolojik göstergeden sadece verilen zaman aralığında eşik üzerinde olan deri iletkenliği tepkilerinin toplam yüksekliği (EÜTopTep- 
Yük) ile pozitif korelasyon göstermiştir $(r(1003)=.08, p<.05)$. Daha çok heyecanlandığını belirten katılımcıların eşik üstü deri iletkenliği tepkilerinin de daha yüksek olduğu görülmüştür. Dolayısıyla tüm örneklem grubu incelendiğinde sonuçlar H3’ü kısmen desteklemiştir.

Aynı analizler her yaş grubu için bağımsız olarak tekrarlandığında farklı bir örüntü bulunmuştur. Genç yaş grubunda öz-bildirimler beş fizyolojik göstergeden üç tanesi ile anlamlı düzeyde korelasyon göstermiştir (EÜTepSay, $r(330)=.22, p<.01$; EÜTepSür, $r(275)=-.81, p<.01$ ve EÜTopTepYük, $r(329)=.13 p<.05)$. Daha çok heyecanlandığ1$\mathrm{n}$ belirten genç yetişkinlerin eşik üstü tepki sayısının ve toplam tepki yüksekliğinin daha fazla, ilk eşik üstü tepkilerinin ortaya çıkma süresinin ise daha kısa olduğu görülmüştür. Orta yaşlı katılımcıların öz-bildirimleri, eşik üstü tepki sayısı $(r(318)=-.14, p<.05)$, eşik üstü tepkilerinin toplam yüksekliği $(r(317)=.13 p<.05)$ ve bu tepkilerinin toplam yaygınlık alanı $(r(318)=-.19, p<.05)$ ile anlamlı düzeyde korelasyon göstermiştir. Daha çok heyecanlandığını belirten orta yaşlı katılımcıların eşik üstü tepkilerinin toplam yüksekliği daha fazla iken eşik üstü tepki sayılarının ve bu tepkilerin toplam yaygınlık alanının daha az olduğu gözlenmiştir. Son olarak, ileri yaştaki yetişkinlerde öz-bildirimleri eşik üstü tepkilerin toplam yüksekliği $(r(356)=.15, p<.01)$, toplam yaygınlık alanı $(r(356)=.24, p<.01$ ve ortalama tonik aktivite $(r(356)=-.36, p<.01)$ ile anlamlı düzeyde korelasyon göstermiştir. Daha çok heyecanlandığını belirten ileri yaştaki katılımcıların eşik üstü tepkilerinin toplam yüksekliğinin ve toplam yaygınlık alanının fazla, ortalama tonik aktivitelerinin ise daha düşük olduğu görülmüştür. Özetle, tüm analizlerde öz-bildirimlerle tutarlı bir şekilde anlamlı korelasyon gösteren ortak gösterge eşik üstü deri iletkenliği tepkilerinin toplam yüksekliğidir. Bu değişken hem tüm örneklemde hem tüm yaş gruplarında öz-bildirim ile anlamlı düzeyde pozitif korelasyon göstermiştir. Diğer fizyolojik göstergeler yaş grupları arasında farklı örüntüler göstermiştir. Sonuç olarak, analizler yaş grupları bazında tekrarlandığında da H3'e kısmi destek sağlamıştır.

\section{Olayların Fenomonolojik Özelliklerinin İncelenmesi (H4)}

Hatırlanan (EB) ve bilinen (SB) toplumsal olaylar tüm fenomonolojik özellikler açısından karşılaştırılmıştır. Bulgular hatırlanan toplumsal olayların bilinen olaylara kıyasla hem kodlama ve hatırlama anındaki duygusal yoğunluk açısından hem de olayların toplum ve kişi için önemi açısından daha yüksek, duygu yükü açısından ise daha düşük olduğunu göstermiş ve H4a'yı desteklemiştir. Episodik ve semantik belleğin fenomonolojik özellikler açısından karşılaştırılmasına ilişkin istatistiksel değerler Tablo 3 'te verilmiştir. 
Tablo 3. Hatırlanan (EB) ile Bilinen (SB) Toplumsal Olayların Fenomonolojik Özelliklerinin Karşılaştırılması

\begin{tabular}{lccccc}
\hline Değişken & $\boldsymbol{X}$ & $\boldsymbol{S S}$ & $\boldsymbol{t}$ & $\boldsymbol{d} \boldsymbol{f}$ & $\boldsymbol{p}$ \\
\hline Duygu yoğunluğu (k) & & & -20.94 & 522 & .000 \\
Bilinen (SB) & .06 & .41 & & & \\
Hatırlanan (EB) & 2.90 & 1.39 & & 522 & .000 \\
Duygu yoğunluğu (h) & .02 & .14 & -18.16 & & \\
Bilinen (SB) & 2.30 & 1.30 & & 522 & .000 \\
Hatırlanan (EB) & & & -25.46 & & \\
Toplum için önemi & .07 & .54 & & 522 & .000 \\
Bilinen (SB) & 3.51 & 1.37 & & & \\
Hatırlanan (EB) & & & -19.59 & & \\
Kişi için önemi & .07 & .54 & & & \\
Bilinen (SB) & 2.81 & 1.42 & & & \\
Hatırlanan (EB) & & & & & \\
Duygu yükü & -.02 & .14 & & & \\
Bilinen (SB) & -.35 & 1.24 & & & \\
Hatıllanan (EB) & & & & & \\
\hline
\end{tabular}

SB: Semantik bellek, EB: Episodik bellek

Fenomonolojik özelliklerin heyecanlanma düzeyi ile ilişkisi incelenmiştir. Öz-bildirime dayalı heyecan düzeyi kodlama $(r(1025)=.97, p<.01)$ ve hatırlama anındaki $(r(1025)=.89, p<.01)$ duygusal yoğunluk, olayın toplum $(r(1025)=.89, p<.01)$ ve kişi $(r(1025)=.92, p<.01)$ için önemi ile pozitif korelasyon gösterirken, olayın duygu yükü $(r(1025)=-.20, p<.01)$ ile negatif korelasyon göstermiştir. Özetle, H4b'de beklenildiği üzere katılımcılar daha çok heyecanlandıklarını belirttikleri olayların aynı zamanda daha önemli, duygusal açıdan daha yoğun ve olumsuz olaylar olduğunu belirtmişledir. Aynı analizler fizyolojik ölçümlere dayanan heyecanlanma düzeyi için de yapılmıştır. Eşik üstü tepki sayısı, tepki süresi ve toplam yaygınlık alanı hiçbir fenomonolojik özellik ile anlamlı düzeyde korelasyon göstermezken, ortalama tonik aktivite sadece olayın toplum için olan önemi ile negatif korelasyon göstermiştir $(r(1005)=$ $-.07, p<.05)$. Eşik üstü toplam tepki yüksekliği ise duygu yükü hariç diğer tüm olay özellikleri ile pozitif korelasyon göstermiştir. Eşik üstü toplam tepki yüksekliği arttıkça olayın yarattığı duygu yoğunluğunun (kodlama, $r(1004)=.07, p<.05$; hatırlama, $(r(1004)=.07, p<.05)$ ve öneminin (toplum, $r(1004)=.11, p<.05$; kişi, $(r(1004)=$ $.08, p<.05)$ de arttığı gözlemlenmiş̧ir. Önceki bulgularda olduğu gibi fizyolojik heyecanlanma ölçümlerinin beş göstergesi olay özelliklerinin analizlerinde de farklı örüntüler göstermiş ve H4b'yi kısmen desteklemiştir. 


\section{Heyecanlanma Düzeyi ve Yaş Arasındaki İlişki}

Araştırmada katılımcının yaşı ile heyecanlanma düzeyi arasındaki ilişki de incelenmiştir. Bu ek analizin sebebi giriş bölümünde de belirtildiği üzere bellek süreçlerinin yaşa bağlı olarak değişkenlik göstermesi ve bu durumun olası farklılıklara sebebiyet vermesinin muhtemel olmasıdır. Bulgular yaşla beraber öz-bildirime dayalı heyecanlanmanın arttığını göstermiştir $(r(1025)=.07, p<.05)$. Fizyolojik heyecanlanma için ise artan yaşla beraber eşik üstü tepki sayısı $(r(1017)=-.18, p<.01)$, bu tepkilerin toplam yüksekliği $r(1016)=-.39, p<.01)$ ve yaygınlık alanı $r(1017)=-.30, p<.01)$ anlamlı düzeyde düşüş göstermiştir. Bu korelasyon analizlerine ek olarak üç yaş grubunun öz-bildirim ve fizyolojik ölçümlere dayalı heyecanlanma düzeyleri tek yönlü varyans analizi (One-Way ANOVA) ile karşılaştırılmıştır. Öz-bildirime dayanan heyecanlanma düzeyi üç grup araSinda anlamlı bir farkl1lık göstermemiştir $(F(2,1023)=1.24, M S E=3.86, p<.05)$. Fizyolojik ölçümlere dayalı heyecanlanma ise beş gösterge için de anlamlı farklılıklar göstermiştir. Bu analizlere dair tüm istatistiksel değerler Tablo 4’te sunulmuştur.

Tablo 4. Genç, Orta ve İleri Yaştaki Yetişkinlerin Öz-bildirime ve Fizyolojik Ölçümlere Dayalı Heyecanlanma Düzeylerinin Karşılaştırılması

\begin{tabular}{lccccc}
\hline Değişken & $\boldsymbol{N}$ & $\boldsymbol{X}$ & $\boldsymbol{S S}$ & $\boldsymbol{F}$ & $\boldsymbol{p}$ \\
\hline Öz-bildirim & & & & 1.24 & .289 \\
Genç & 350 & 1.17 & 1.51 & & \\
Orta & 319 & 1.22 & 1.93 & & \\
İleri & 357 & 1.37 & 1.83 & & .000 \\
EÜTepSay & & & & 39.64 & \\
Genç & 330 & 3.58 & 1.94 & & \\
Orta & 331 & 2.37 & 1.85 & & .018 \\
İleri & 357 & 2.57 & 1.87 & & \\
EÜTepSür & & & & \\
Genç & 275 & 1.47 & .49 & & \\
Orta & 236 & 1.60 & .60 & & \\
İleri & 266 & 1.56 & .57 & & \\
EÜTopTepYük & & & & & \\
Genç & 330 & 6.37 & 7.22 & & .000 \\
Orta & 330 & .99 & 2.06 & & \\
Illeri & 357 & 1.36 & 2.35 & & \\
EÜTopYayAl & & & & 59.66 & \\
Genç & 330 & 14.78 & 20.08 & & \\
Orta & 331 & 5.54 & 7.85 & & \\
İleri & 357 & 4.53 & 9.10 & & \\
OrtTonAk & & & & 54.83 & \\
Genç & 330 & -3.34 & 5.91 & & \\
Orta & 331 & -.55 & 1.94 & & \\
İleri & 357 & -.93 & 1.95 & & \\
\hline
\end{tabular}

EÜTepSay: Verilen zaman aralığında eşik üzerinde olan tepkilerin sayısı, EÜTepSür: İlk eşik üzeri tepkinin ortaya çıma süresi, EÜTepTopYük: Verilen zaman aralığında eşik üzerinde olan deri iletkenliği tepkilerinin toplam yüksekliği, EÜTopYayAl: Verilen zaman aralığında eşik üzerinde olan deri iletkenliği tepkilerinin toplam yaygınlık alanı, OrtTonAk: Ortalama tonik (uyarıcı etkiye yönelik olan) aktivite 
Tablo 4'te de görüldüğü üzere fizyolojik heyecanlanma göstergelerinin beşinde de tutarlı olarak gençler diğer iki yaş grubundan anlamlı farklılıklar göstermişlerdir. Gençlerin eşik üstü tepki sayısı, bu tepkilerin toplam yüksekliği ve yaygınlık alanı ile ortalama tonik aktivite düzeyleri her iki yaş grubundan da yüksektir. Eşik üstü tepki süreleri ise orta ve ileri yaştaki katılımcılarınkinden anlamlı düzeyde kısadır. Özetle, gençler diğer iki yaş grubuna oranla daha fazla ve daha hızlı heyecanlanma göstermişlerdir. Orta ve ileri yaştaki yetişkinlerin fizyolojik ölçümlere dayalı heyecanlanma düzeyleri arasında ise anlamlı bir fark saptanmamıştır.

\section{TARTIŞMA}

Bu çalışmada toplumsal olaylara dair episodik (EB) ve semantik bellek (SB) süreçlerinin heyecanlanma düzeyi ile ilişkileri üç farklı yaş grubunda iki farklı ölçüm tipi kullanılarak incelenmiştir. Başka bir ifadeyle, heyecanlanma düzeyi hem katılımcıların öz-bildirimlerine dayanarak hem de GSR cihazı kullanılarak fizyolojik ölçümlerle belirlenmiştir. Bulgular örneklem genelinde ve yaş grupları özelinde incelenmiştir. Bu kapsamda değerlendirmeler aşağıda detaylarıyla tartışılmıştır.

Heyecanlanma düzeyi ile EB ve SB performansları arasındaki ilişkiye dair bulgular katılımcıların öz-bildirimlerine dayalı heyecanlanma düzeyinin bellek performanslarıyla ilişkili olduğunu göstermiştir. Katılımcıların belirttikleri heyecanlanma düzeyi arttıkça hatırlanan episodik detay ve toplam semantik doğru puanları da artış göstermiştir. $\mathrm{Bu}$ bulgular tüm yaş grupları için aynıdır. Dolayısıyla, beklenildiği gibi öz-bildirime dayalı heyecan arttıkça EB ve SB performansı da yükselmiştir. Önceki çalışmalarda kişilerin toplumsal olaylara dair öznel güvenilirliklerinin ve tutarlılıklarının düşük olduğu ve olayları yanlış hatırlasalar bile doğru hatırladıklarına dair inançlarının yüksek olduğu gözlemlenmiştir (Kensinger ve Corkin, 2004; Talarico ve Rubin, 2007).

Heyecanlanma düzeyinin EB performansı ile ilişkisi fizyolojik heyecanlanma ölçümleri baz alınarak da incelenmiştir. GSR ölçümlerinde fizyolojik heyecanlanmanın beş farklı göstergesi olduğundan bulgular yaş grupları arasında ve her yaş grubunun kendi içinde farklı örüntüler göstermiştir. Örneğin, EB performansı ile pozitif korelasyon gösteren fizyolojik göstergeler tüm yaş gruplarında aynı değildir. Nitekim gençlerde ve orta yaşlılarda eşik üstü tepki sayısı arttıkça hatırlanan episodik detay da artmıştır. İleri yaş grubunda ise eşik üstü tepkilerin toplam yüksekliği, yaygınlık alanı ve tonik aktivite yükseldikçe EB performansı artış göstermiştir. Daha önce de belirtildiği üzere 
yaşlanmayla beraber birçok fizyolojik ve bilişsel değişim görülmektedir (Cabeza, 2001; Light, 1991; Raz, 2000; Spilich, 1983) Bu değişimlerin ise fizyolojik ölçümlere dayanan heyecanlanma düzeyindeki farklılıklarla ilişkili olması mümkündür. Bu nedenle fizyolojik ölçümlere dayanan her türlü çalışmada yaş grupları arasındaki olası farklılıkları ve yaşlanmaya eşlik eden fizyolojik değişimleri dikkate almak sonuçların geçerliliği ve güvenilirliği açısından önem taşımaktadır.

Bu çalışmada fizyolojik heyecanlanma düzeyinin SB performansı ile olan ilişkisi de incelenmiştir. Yaş grupları arasındaki önemli farklılıklardan birisi eşik üstü tepki süresinin sadece ileri yaş grubunda SB performansı ile ilişkili olmasıdır. Tepki süresi uzadıkça hatırlanan semantik doğru miktarı artış göstermiştir. Başka bir deyişle, daha uzun sürede tepki veren ileri yaşlı kişiler daha iyi SB performansı göstermişlerdir. Dikkat çeken bir başka bulgu ise eşik üstü tepki sayısının toplam semantik doğru puanı ile gençlerde pozitif, diğer iki yaş grubunda ise negatif korelasyon göstermiş olmasıdır. Bu durumda heyecanlanma düzeyindeki artış gençlerde SB performansında artışla ilişkili iken orta ve ileri yaşlarda daha düşük SB performansı ile ilişkilidir. Bunun sebebi orta ve ileri yaşlarda heyecanlanmaya eşlik eden fizyolojik değişimlerin SB performansını olumsuz etkilemesi olabileceği gibi katılımcıların doğru cevapları bilemeyince veya hatırlayamayınca kaygı duyup daha çok heyecanlanmaları da olabilir. Dolayısıyla, ileri yaş gruplarında fizyolojik heyecanlanma düzeyi ile bellek performansı arasındaki ilişkiyi inceleyecek olan gelecek araştırmaların bu iki ihtimali birbirinden ayrıştırabilecek araştırma dizaynları geliştirmeleri çok önemlidir.

Bulgular H2a’y1 doğrulayarak EB süreçlerine dair öznel heyecanlanma düzeyinin SB süreçlerine kıyasla daha yüksek olduğunu göstermiştir. Bu sonuç her yaş grubu için ayrı incelendiğinde de değişmemiştir (H2c). Bu tarz flaş bellek örneği oluşturan toplumsal olaylar, doğaları gereği daha fazla duygusal uyarım, dolayısıyla heyecanlanma içermektedir (Brown ve Kulik, 1977). Buna ek olarak, Tulving'in (1995) yaptığg EB ve SB ayrımına bakılırsa, episodik olayların bilinçli ve aktif olarak hatırlanıyor olma özelliği de aşinalık içeren semantik hatırlamaya kıyasla daha fazla duygusal uyarıma neden oluyor olabilir. Ayrıca, buradaki farklılıkların öznel değerlendirmeye dayalı olduğu düşünülürse, olayı sadece bilmek yerine hatırlıyor olmaları bile katılımcıların heyecanlanmaya dair öz-bildirimlerinin daha yüksek olmasına neden olmuş olabilir. Flaş bellek üzerine olan geçmiş araştırmalar, kişilerin toplumsal olayları hatırlarken olayı ilk öğrendikleri andaki heyecanlarını da hatırladıklarını ve bunu bellek performanslarına dair bir kısa yol (heuristic) olarak kullandıklarını göstermiştir (Kensinger ve Corkin, 2004; Talarico ve Rubin, 
2007). Dolayısıyla, bu araştırmada katılımcıların her toplumsal olay için yaptıkları bilme/hatırlama değerlendirmesi heyecanlanma düzeylerine dair öznel değerlendirmelerini etkilemiş olabilir (Dougal ve Rotello, 2007; Sharot, Delgado ve Phelps, 2004). Kişiler hatırladıkları olaylar için daha fazla heyecanlandıklarını ya da bildikleri olaylar için daha az heyecanlandıklarını varsaymış ve gerçek heyecan düzeylerinden ziyade bilme/hatırlama durumlarına göre çıkarım veya yorum yapmış olabilirler. Sonuç olarak, kişilerin öznel heyecanlanma değerlendirmeleri yaşlarından bağımsız olarak tutarlı bir şekilde SB süreçlerine kıyasla EB için daha yüksek değerler göstermiştir.

Fizyolojik heyecanlanma düzeyi açısından ise iki bellek sistemi arasında tüm örnekleme bakıldığında genel olarak anlamlı bir fark olmadığ 1 görülmüştür. Ancak, yaş grupları bağımsız olarak incelendiğinde sadece genç yetişkinlerde SB süreçlerine kıyasla, EB süreçlerine dair fizyolojik tepki sayısının daha fazla, tepsi süresinin ise daha kısa olduğu görülmüştür. Başka bir deyişle, gençler bildikleri toplumsal olaylara kıyasla hatırladıkları olaylar için daha fazla ve daha hızlı bir heyecanlanma göstermişlerdir. $\mathrm{Bu}$ tarz bir örüntünün orta ve ileri yaş gruplarında gözlemlenmemiş olması yaşlanmayla beraber ortaya çıkan fizyolojik ve bilişsel değişimlerle ilişkili olabilir. Örneğin, Grady (2001) yaşlanmaya genellikle davranışsal, bilişsel ve fizyolojik düzeyde birçok değişikliğin eşlik ettiğini öne sürmüştür. Bellek süreçleri de yaşlılıkla beraber düşüşle ilişkilendirilen bilişsel alanlardan biridir (Cabeza, 2001; Light, 1991; Raz, 2000; Spilich, 1983).

Önceki araştırmalar bellek performansında yaşa bağlı düşüşler gözlemlemiştir (Cabeza, 2001; Light, 1991; Raz, 2000; Spilich, 1983). Bu çalışmalardan bazıları farklı bellek sistemlerinin yaşlanma süreçlerinden aynı derecede etkilenmediğini ortaya koymuştur. Örneğin, yaşlanmayla beraber EB performansı düşerken SB performansı etkilenmemektedir (McIntyre ve Craik, 1987; Spencer ve Raz, 1995; Zacks ve ark., 2000). Bu geçmiş bulgulardan dolayı yaş grupları arasındaki olası heyecanlanma düzeyi farklılıkları da incelenmiştir. Fizyolojik ölçümlere dayalı bulgular ilerleyen yaşla beraber heyecanlanma düzeyinde düşüş gösterirken, öz-bildirimlere dayalı heyecanlanmanın yaşla beraber arttığ1 görülmüştür. Birbirinin aksi yönde olan bu iki bulgu, araştırmalarda öznel değerlendirmelere ek olarak objektif ölçümler yapılmasının önemini göstermektedir. Bu bulgular gruplar arası karşılaştırmalarla daha detaylıca incelenmiş ve üç yaş grubu öz-bildirime dayalı heyecanlanma düzeylerinde birbirlerinden farklı değil iken, fizyolojik heyecanlanmayı ölçen beş gösterge için de anlamlı düzeyde farklı heyecanlanma seviyeleri göstermişlerdir. Gençler diğer iki yaş grubuna göre fizyolojik ölçümler baz alındığında hem 
daha fazla hem daha hızlı heyecanlanmışlardır. Özetle, benzer şekilde fizyolojik ölçümlere dayalı analizler beklentileri desteklerken öz-bildirimlere dayalı karşılaştırmalar beklenenin aksine bulgular ortaya koymuştur. Bu bulgular, otobiyografik bellek araştırmalarında sık kullanılan öz-bildirimlerin güvenilirliğine dikkat çekmekte ve bu değerlendirmelerin araştırmanın daha güçlü olması açısından objektif ölçümlerle desteklenmesinin veya sağlamasının yapılmasının önemini göstermektedir.

Bulguların genel olarak fizyolojik ölçümlere dayanan heyecanlanma ile öz-bildirime dayanan heyecanlanma düzeyleri için farklı örüntüler göstermesi bu iki ölçüm arasındaki tutarlılığına dair soru işaretleri oluşturmaktadır. Bu araştırmada öznel ve objektif ölçümlerin birbirleriyle olan korelasyonları incelenmiş ve bulgular öz-bildirimlerin beş fizyolojik göstergeden sadece birisiyle ilişkili olduğunu göstermiştir. Öznel değerlendirmelerle belirlenen heyecanlanma düzeyi arttıkça eşik üstü tepkilerin toplam yüksekliğinde de artış gözlemlenmiştir. Tüm örneklem grubunda gözlemlenmiş olan bu bulgu, her yaş grubu için bağımsız olarak incelendiğinde ise farklı örüntüler elde edilmiştir. Her yaş grubunda, öz-bildirimler fizyolojik göstergelerden üçer tanesiyle pozitif korelasyon göstermiştir. Özetle, yaş grubuna ve söz konusu olan fizyolojik göstergeye göre bu iki farklı ölçüm tipi (öznel ve objektif) arasındaki tutarlılık farklılıklar göstermiştir. $\mathrm{Bu}$ farklılıklar da yine yaş grupları arasındaki heyecanlanma farklılıkları ve fizyolojik değişimlerle bağlantılı olabilir. Belirtildiği üzere yaş grupları arasında heyecanlanma düzeylerinde farklılıklar bulunmuştur ve bu farklılıklar öznel ölçümlerle olan ilişkilerine yansıyabilmektedir. Ayrıca, her yaş grubunun fizyolojik özellikleri de birbirinden farklı olduğundan (örn., Cabeza, 2001; Light, 1991; Raz, 2000; Spilich, 1983) bu durumun farklı örüntüler görülmesinde etkili olabileceği düşünülmüştür.

Otobiyografik bellek çalışmalarında hatırlanan olayların duygu yükü ve önemi gibi belirli fenomonolojik özellikler açısından değerlendirilmesi yaygın olarak kullanılan bir yöntemdir. Bu araştırmada da katılımcılar sunulan her toplumsal olayı duygu yükü, duygusal yoğunluk (kodlama ve hatırlama sırasındaki) ve önem (toplum ve kişi için) açısından değerlendirmişlerdir. Bulgular beklenildiği gibi hatırlanan toplumsal olayların bilinen olaylara kıyasla hem kodlama hem hatırlama sırasındaki duygu yoğunluğunun daha fazla olduğunu, toplum ve kişi için öneminin daha yüksek değerlendirildiğini ve duygu yükü yönünden ise daha olumsuz görüldüğünü göstermiştir. Burada katılımcıların verilen olayı hatırlıyor olmaları bir kısa yol görevi görmüş ve fenomonolojik özelliklere dair öznel değerlendirmelerini etkilemiş olabilir. Öte yandan, katılımcılar bilinen olayların detaylarını 
hatırlamadıkları için bu olaylara ait özellikleri daha düşük değerlendirmiş olabilirler. Sonuç olarak, EB ve SB süreçleri arasında toplumsal olayların fenomonolojik özellikleri açısından anlamlı farklılıklar gözlemlenmiştir. Bu farklılıklara neden olan olası diğer faktörlerin incelenmesi gelecek çalışmalar için geniş bir araştırma alanı sunmaktadır.

Toplumsal olayların fenomonolojik özelliklerinin heyecanlanma düzeyi ile olan ilişkisi hem öznel hem fizyolojik değerlendirmeler için incelenmiştir. Beklenildiği gibi öz-bildirime dayalı heyecanlanma düzeyi arttıkça olayın duygusal yoğunluğu (kodlama ve hatırlama sırasındaki) ve önemi (toplum ve kişi için) de artmış, duygu yükü ise daha olumsuz olarak değerlendirilmiştir. Fizyolojik tepkilere dayalı heyecanlanma incelendiğinde ise sonuçlar yine beş gösterge için farklı örüntüler göstermiştir. Beş göstergeden üçü olan eşik üstü tepki sayısı, tepki süresi ve bu tepkilerin yaygınlık alanı fenomonolojik özellikler ile anlamlı bir ilişki göstermemiştir. Eşik üstü toplam tepki yüksekliğindeki artışın ise olayın duygusal yoğunluğundaki (kodlama ve hatırlama sırasındaki) ve önemindeki (toplum ve kişi için) artışla ilişkili olduğu görülmüştür. Duygusal açıdan daha yoğun değerlendirilen ve hem kişi hem toplum için önemi daha fazla görülen olayların hatırlanması sırasındaki eşik üstü tepkilerin yüksekliğinin de daha fazla olduğu bulunmuştur. Fizyolojik ölçümlere dayanan heyecanlanma ile toplumsal olayların fenomonolojik özellikleri arasındaki ilişkiye dair sonuçlar çok net ve tutarlı bir tablo çizmektedir. Bu nedenle, bu ilişki farklı örneklem grupları ve yöntemlerle tekrarlanmalıdır.

Sonuç olarak, alan yazına bakıldığında heyecanlanma ve bellek süreçleri arasındaki ilişkiyi araştıran çalışmaların çoğunlukla kelimelerin hatırlamasına odaklandığı görülmektedir (örn., Buchanan, 2007; Kensinger ve Corkin, 2003, 2004; Talmi ve Moscovitz, 2004). Bu araştırmalar genellikle kişilerin heyecan uyandıran resim veya kelime gibi uyaranları daha hızlı ve başarılı olarak hatırladıklarını göstermektedir. Ayrıca, kelime gibi uyaranları hatırlamaya dayanan sonuçları ilkokuldaki ilk günümüz gibi bireysel anılarımızı içeren OB süreçlerine genellemek yanıltıcı olabilir. Buna ek olarak, toplumsal olaylara dair bellek süreçlerinin de kelime listesi hatırlamaya çalışırken kullanılan süreçlerden farklı olması olasıdır. Dolayısıyla, liste uyaranlarını hatırlama, günlük hayatımızdaki bellek süreçlerini birebir yansıtmıyor olabileceğinden, toplumsal olayların hatırlanması ile heyecanlanma düzeyi arasındaki ilişkiyi açıklamakta yetersiz kalabilir. $\mathrm{Bu}$ araştırmada toplumsal olayların hatırlanması sırasındaki heyecanlanma düzeyi hem katılımcıların öz-bildirimlerine hem de cihazlarla yapılan fizyolojik ölçümlere dayanarak ölçülmüş ve bu ölçümler episodik ve semantik bellek süreçleri için karşılaştırılmıştır. 
Araştırmanın önemli bir katkısı sübjektif ve objektif değerlendirmeler arasındaki farklılıkları göstermesi ve öznel değerlendirmelerin, fizyolojik ölçümler gibi objektif değerlendirmelerle sağlamasının yapılması gerekliliğine dikkat çekmesidir. Fakat, çalışmada kullanılan fizyolojik yöntemde beş farklı gösterge olması ve bu göstergelere dair bulguların çok tutarlı olmaması genel bir sonuca varmayı ve yorum yapmayı zorlaştırmıştır. Fizyolojik ölçümlere odaklanmayı hedefleyen gelecek çalışmalar, daha az sayıda ve mümkünse tek göstergesi olan ölçümler kullanırsa bulgular daha net olacaktır. Buna ek olarak, fizyolojik ölçümler ve bilişsel süreçler söz konusu olduğunda yaş önemli bir değişken haline geldiğinden farklı yaş gruplarından veri toplanması ve karşılaştırılması da önem kazanmaktadır. Bu araştırma toplumsal olaylara dair episodik ve semantik bellek süreçlerini üç farklı yaş grubunda öznel ve objektif ölçümlerle karşılaştırarak bu anlamda alan yazına önemli bir katkıda bulunmuştur.

Özetle, EB ve SB süreçleri karşılaştırıldığında episodik hatırlamanın öz-bildirimler bazında her yaş grubunda daha yüksek heyecanlanma düzeyi ile ilişkiliyken fizyolojik ölçümler bazında sadece bazı göstergelere göre daha fazla heyecanlanma gösterdiği gözlemlenmiştir. Benzer bulgular heyecanlanma düzeyi arttıkça EB ve SB performansında görülen değişimler ve fenomonolojik özelliklerin değerlendirilmesinde de görülmüştür. Öz-bildirimlerin her zaman beklenen yönde ve tutarlı sonuçlar gösterirken fizyolojik ölçümlere ait bulguların daha çeşitlilik göstermesi iki şekilde açıklanabilir. Birincisi, daha önce bahsedildiği üzere bu çalışmada kullanılan fizyolojik ölçüm yöntemi ve analizi bu araştırma için en uygun yöntem olmayabilir. İkincisi ise kişilerin öz-bildirimleri tamamen kendi deneyimleri ve bilgileri bazında yaptıkları çıkarım ve yorumlar olduğundan toplanan diğer verilerle daha yüksek tutarlılık göstermiş olabilir. Gelecek çalışmaların bu iki ihtimali test edebilecek şekilde tasarlanması alan yazına büyük katkı sağlayacak ve bu çalışmada cevaplanamamış olan araştırma sorularına da 1şık tutacaktır.

\footnotetext{
Hakem Değerlendirmesi: Dış bağımsız.

Çıkar Çatışması: Yazar çıkar çatışması bildirmemiştir.

Finansal Destek: Yazar bu çalışma için finansal destek almadığını beyan etmiştir.

Peer-review: Externally peer-reviewed.

Conflict of Interest: The author has no conflict of interest to declare.

Grant Support: The author declared that this study has received no financial support.
} 


\section{Kaynakça}

Addis, D. R., Wong, A. T. ve Schacter, D. L. (2008). Age-related changes in the episodic simulation of future events. Psychological Science, 19(1), 33-41. doi: 10.1111/j.1467-9280.2008.02043.x.

Adolphs, R., Denburg, N. L. ve Tranel, D. (2001). The amygdala's role in long-term declarative memory for gist and detail. Behavioral Neuroscience, 115, 983-992. doi: 10.1037//0735-7044.115.5.983

Anderson, A. K., Wais, P. E. ve Gabrieli, J. D. E. (2006). Emotion enhances remembrance of neutral events past. Proceedings of the National Academy of Sciences USA, 103, 1599-1604. doi: 10.1073/ pnas.0506308103

Atkinson, R. C. ve Shiffrin, R. M. (1971). The control of short-term memory. Scientific American, 225, 82-90. doi: 10.1038/scientificamerican0871-82

Berntsen, D. (2002). Tunnel memories for autobiographical events: Central details are remembered more frequently from shocking than from happy experiences. Memory \& Cognition, 30(7), 10101020. doi: 10.3758/BF03194319

Borrini, G., Dall'ora, P., Della-Sala, S., Mainelli, L. ve Spinnler, H. (1989). Autobiographical memory: Sensitivity to age and education of a standardized enquiry. Psychological Medicine, 19, 215-224. doi: $10.1017 / \mathrm{s} 0033291700011181$

Bradley, M. M., Codispoti, M., Sabatinelli, D., Cuthbert, B. N. ve Lang, P. J. (2001). Emotion and motivation II: Sex differences in picture processing. Emotion, 1(13), 300-319. doi: 10.1037//15283542.1.3.300

Bradley, M. M., Greenwald, M. K., Petry, M. C. ve Lang, P. J. (1992). Remembering pictures: Pleasure and arousal in memory. Journal of Experimental Psychology: Learning, Memory, and Cognition, 18, 379-390. doi: 10.1037//0278-7393.18.2.379

Brown, R. ve Kulik, J. (1977). Flashbulb memories. Cognition, 5, 73-99. doi: 10.1016/00100277(77)90018-X

Buchanan, T.W. (2007). Retrieval of emotional memories. Psychological Bulletin, 133, 761-779. doi: 10.1037/0033-2909.133.5.761

Burke, A., Heuer, F. ve Reisberg, D. (1992). Remembering emotional events. Memory and Cognition, 20, 277-290. doi: 10.3758/BF03199665

Burns, A., Greene, B. R., McGrath, M. J., O’Shea, T. J., Kuris, B., Ayer S. M., ... Cionca, V. (2010). Shimmer-A wireless sensor platform for noninvasive biomedical research. Sensors Journal, 10, 1527-1534. doi: 10.1109/JSEN.2010.2045498

Cabeza, R. (2001). Functional neuroimaging of cognitive aging. R. Cabeza ve A. Kingstone (Ed.), Handbook of functional neuroimaging of cognition içinde (s. 331-377). Cambridge, MA: MIT Press.

Cohen, G. ve Faulkner, D. (1988). Life span changes in autobiographical memory. M. M. Gruneberg, P. E. Morris ve R. N. Sykes (Ed.), Practical aspects of memory: Current research and issues, Vol. 1. Memory in everyday life içinde (s. 277-282). Oxford, England: John Wiley \& Sons.

Conway, M. A. ve Pleydell-Pearce, C. W. (2000). On the construction of autobiographical memories in a self-memory system. Psychological Review, 107, 261-288. doi: 10.1037/0033-295x.107.2.261

Conway, M. A., Wang, Q., Hanyu, K. ve Haque, S. (2005). A cross-cultural investigation of autobiographical memory: On the universality and cultural variation of the reminiscence bump. Journal of Cross-Cultural Psychology, 36(6), 739-749. doi: 10.1177/0022022105280512

Craik, F. I. M. ve McDowd, J. M. (1987). Age differences in recall and recognition. Journal of Experimental Psychology: Learning, Memory, and Cognition, 13, 474-479. doi: 10.1037/02787393.13.3.474 
Daselaar, S. M., Rice, H. J., Greenberg, D. L., Cabeza, R., LaBar, K. S. ve Rubin, D. C. (2008). The spatiotemporal dynamics of autobiographical memory: Neural correlates of recall, emotional intensity, and reliving. Cerebral Cortex, 18(1), 217-229. doi: 10.1093/cercor/bhm048

Demiray, B. ve Bluck, S. (2011). The relation of the conceptual self to recent and distant autobiographical memories. Memory, 19(8), 975-992. doi:10.1080/09658211.2011.626427

Dixon, R. A., De Frias, C. M. ve Maitland, S. B. (2001). Memory in midlife. M. E. Lachman (Ed.), Handbook of midlife development içinde (s. 248-278). New York: Wiley. doi:10.1016/B0-08043076-7/01695-8

Dougal, S. ve Rotello, C. (2007). 'Remembering' emotional words is based on response bias, not recollection. Psychonomic Bulleting \& Review, 14, 423- 429. doi: 10.3758/BF03194083

Esen, F., Celebi, G., Ertekin, C. ve Colakoglu, Z. (1997). Electrodermal activity in patients with Parkinson's disease. Clinical Autonomic Research, 7(1), 35-40. doi: 10.1007/bf02267624

Fischer, H., Nyberg, L., Karlsson, S., Karlsson, P., Brehmer, Y., Rieckmann, A., . . Bäckman, L. (2010). Simulating neurocognitive aging: Effects of a dopaminergic antagonist on brain activity during working memory. Biological Psychiatry, 67(6), 575-580. doi: 10.1016/j.biopsych.2009.12.013

Folstein, M. F., Folstein. S. ve McHugh, P. R. (1975). "Mini Mental State" A practical method for grading the cognitive state of patients for the clinician. Journal of Psychiatric Research, 12, 189198. doi: 10.1016/0022-3956(75)90026-6

Gabrieli, J. D. E. (1998). Cognitive neuroscience of human memory. Annual Review of Psychology, 49, 87-115. doi: 10.1146/annurev.psych.49.1.87

Gavazzeni, J., Wiens, S. ve Fischer, H. (2008). Age effects to negative arousal differ for self-report and electrodermal activity. Psychophysiology, 45(1), 148-51. doi: 10.1111/j.1469-8986.2007.00596.x

Grady, C. L. (2001). Age-related changes in the functional neuroanatomy of memory. M. NavehBenjamin, M. Moscovitch ve H. Roediger III (Ed.), Perspectives on human memory and cognitive aging: essays in honour of Fergus Craik içinde (s. 265-276). New York: Psychology Press.

Grady, C. L. ve Craik, F. I. M. (2000). Changes in memory processing with age. Current Opinion in Neurobiology, 10, 224-231. doi: 10.1016/S0959-4388(00)00073-8

Graf, P. ve Schacter, D. L. (1985). Implicit and explicit memory for new associations in normal and amnesic subjects. Journal of Experimental Psychology: Learning, Memory and Cognition, 11, 501518. doi: 10.1037//0278-7393.11.3.501

Greenberg, D. L., Rice, H. J., Cooper, J. J., Cabeza, R., Rubin, D. C. ve LaBar, K. S. (2005). Coactivation of the amygdala, hippocampus, and inferior frontal gyrus during autobiographical memory retrieval. Neuropsychologia, 43, 659-674. doi: 10.1016/j.neuropsychologia.2004.09.002

Güngen, C., Ertan, T., Eker, E., Yaşar, R. ve Engin. F. (2002). Reliability and validity of the standardized Mini Mental State Examination in the diagnosis of mild dementia in Turkish population. Turk Psikiyatri Dergisi, 13(4), 273-281.

Hamann, S. (2001). Cognitive and neural mechanisms of emotional memory. Trends in Cognitive Sciences, 5, 394-400. doi: 10.1016/s1364-6613(00)01707-1

Hasher, L. ve Zacks, R. (1979). Automatic and effortfull, processes in memory. Journal of Experimental Psychology: General, 108, 356-388. doi: 10.1037/0096-3445.108.3.356

Holland, C. A. ve Rabbit, P. M. A. (1990). Autobiographical and text recall in the elderly: An investigation of a processing resource deficit. The Quarterly Journal of Experimental Psychology, 42A (3), 441-470. doi: 10.1080/14640749008401232

Keil, A. ve Freund, A. M. (2009). Changes in the sensitivity to appetitive and aversive arousal across adulthood. Psychology and Aging, 24(3), 668. doi: 10.1037/a0016969 
Kensinger, E. A. (2004). Remembering emotional experiences: The contribution of valence and arousal. Reviews in Neurosciences, 15(4), 241-253. doi: 10.1515/revneuro.2004.15.4.241

Kensinger, E. A. ve Corkin, S. (2003). Memory enhancement for emotional words: Are emotional words more vividly remembered than neutral words? Memory and Cognition, 31(8), 1169-1180. doi: $10.3758 / \mathrm{bf} 03195800$

Kensinger, E. A. ve Corkin, S. (2004). Two routes to emotional memory: Distinct neural processes for valence and arousal. Proceedings of the National Academy of Sciences USA, 101, 3310-3315. doi: 10.1073/pnas.0306408101

Khalfa, S., Peretz, I., Jean-Pierre, B. ve Manon, R. (2002). Event-related skin conductance responses to musical emotions in humans. Neuroscience letters, 328, 145-149. doi: 10.1016/s03043940(02)00462-7

Kopelman, M. D., Wilson, B. A. ve Baddeley, A. D. (1989). The autobiographical memory interview: A new assessment of autobiographical and personal semantic memory in amnesic patients. Journal of Clinical and Experimental Neuropsychology, 11(5), 724-744. doi: 10.1080/01688638908400928

Ledalab 3.4.6 -Leipzig ElectroDermal Activity Lab (2015, Mart). Erişim adresi: http://www.ledalab.de

Lee, A. C. H., Robbins, T. W. ve Owen, A. M. (2000). Episodic memory meets working memory in the frontal lobe: Functional neuroimaging studies of encoding and retrieval. Crit Rev Neurobiol, 14, 165-197.

Leigland, L. A., Schulz, L. E. ve Janowsky, J. S. (2004). Age related changes in emotional memory. Neurobiology of Aging, 25, 1117-1124. doi: 10.1016/j.neurobiolaging.2003.10.015

Leiner, D., Fahr, A. ve Früh, H. (2012). EDA positive change: A simple algorithm for electrodermal activity to measure general audience arousal during media exposure. Communication Methods and Measures, 6(4), 237-250. doi: 10.1080/19312458.2012.732627

Levine, B., Svoboda, E., Hay, J. F., Winocur, G. ve Moscovitch, M. (2002). Aging and autobiographical memory: Dissociating episodic from semantic retrieval. Psychology and Aging, 17(4), 677-689. doi: 10.1037/0882-7974.17.4.677

Light, L. L. (1991). Memory and aging: Four hypotheses for data. Annual Review of Psychology, 42, 333-376. doi: 10.1146/annurev.ps.42.020191.002001

Lim, C. L., Rennie, C., Barry, R. J., Bahramali, H., Lazzaro, I., Manor, B. ve Gordon, E. (1997). Decomposing skin conductance into tonic and phasic components. International Journal of Psychophysiology, 25, 97-109. doi: 10.1016/s0167-8760(96)00713-1

MacKay, D. G. ve Ahmetzanov, M. V. (2005). Emotion, memory, and attention in the taboo Stroop paradigm: An experimental analogue of flashbulb memories. Psychological Science, 16, 25-32. doi: 10.1111/j.0956-7976.2005.00776.x

Maguire, E. A. (2001). Neuroimaging studies of autobiographical event memory. Philosophical Transactions of the Royal Society of London, 356, 1441-1451. doi: 10.1098/rstb.2001.0944

Maguire, E. A. ve Frith, C. D. (2003). Lateral asymmetry in the hippocampal response to the remoteness of autobiographical memories. Journal of Neuroscience, 23, 5302-5307. doi: 10.1523/ JNEUROSCI.23-12-05302.2003

Markowitsch, H. J., Thiel, A., Reinkemeier, M., Kessler, J., Koyuncu, A. ve Heiss, W. D. (2000). Right amygdala and temporofrontal activation during autobiographic but not during fictitious memory retrieval. Behavioral Neuroscience, 12, 181-190. doi: 10.1155/2000/303651

McGaugh, J. L. (2004). The amygdala modulates the consolidation of memories of emotionally arousing experiences. Annual Review of Neuroscience, 27, 1-28. doi: 10.1146/annurev. neuro.27.070203.144157 
McIntyre, J. S. ve Craik, F. I. M. (1987). Age differences in memory for item and source information. Canadian Journal of Psychology, 41, 175-192. doi: 10.1037/h0084154

Molloy, D. W. ve Standish, T. I. M. (1997). A guide to the standardized mini mental state examination. International Psychogeriatrics, 9(1), 87- 94. doi:10.1017/s1041610297004754

Multhaup, K. S., Johnson, M. D. ve Tetirick, J. C. (2005). The wane of childhood amnesia for autobiographical and public event memories. Memory, 13, 161-173.

doi:10.1080/09608210344000652

Ochsner, K. N. (2000). Are affective events richly recollected or simply familiar? The experience and process of recognizing feelings past. Journal of Experimental Psychology: General, 129(2), 242261. doi: $10.1037 / / 0096-3445.129 .2 .242$

Phelps, E. A. ve Sharot, T. (2008). How (and why) emotion enhances the subjective sense of recollection. Current Directions in Psychological Science, 17, 147-152. doi: 10.1111/j.1467-8721.2008.00565.x

Piolino, P., Desgranges, B., Benali, K. ve Eustache, F. (2002). Episodic and semantic remote memory in aging. Memory, 10, 239-257. doi: 10.1080/09658210143000353

Piolino, P., Desgranges, B. ve Eustache, F. (2009). Episodic autobiographical memories over the course of time: cognitive, neuropsychological and neuroimaging findings. Neuropsychologia, 47(11), 2314-29. doi: 10.1016/j.neuropsychologia.2009.01.020

Ramponi, C., Handelsman, G. ve Barnard, P. J. (2010). The memory enhancement effect of emotion is absent in conceptual implicit memory. Emotion, 10(2), 294-299. doi: 10.1037/a0018491

Raz, N. (2000). Aging of the brain and its impact on cognitive performance: Integration of structural and functional findings. F. I. M. Craik ve T. A. Salthouse (Ed.), The handbook of aging and cognition içinde (s. 1-90). Mahwah, NJ: Lawrence Erlbaum Associates.

Reisberg, D. ve Heuer, F. (1992). Remembering the details of emotional events. E. Winograd ve U. Neisser (Ed.), Affect and accuracy in recall: Studies of "flashbulb" memories içinde (s. 163-190). Cambridge, MA: Harvard University Press. doi: 10.1017/CBO9780511664069.009

Rugg, M. D., Johnson, J. D., Park, H. ve Uncapher, M. R. (2008). Encoding-retrieval overlap in human episodic memory: A functional neuroimaging perspective. Progress in Brain Research, 169, 339 352. doi: 10.1016/S0079-6123(07)00021-0

Schacter, D. L. (1992). Implicit knowledge: New perspectives on unconscious processes. Proceedings of the National Academy of Sciences, 89(23), 1113-1117. doi: 10.1073/pnas.89.23.11113

Sharot, T., Delgado, M. R. ve Phelps, E. A. (2004). How emotion enhances the feeling of remembering. Nature Neuroscience., 7 , 376-1380. doi: 10.1038/nn1353

Sharot, T. ve Yonelinas, A. P. (2008). Differential time-dependent effects of emotion on the recollective experience and memory for contextual information. Cognition, 106, 538-547. doi: 10.1016/j. cognition.2007.03.002

Spencer, W. D. ve Raz, N. (1995). Differential effects of aging on memory for content and context: A meta-analysis. Psychology and Aging, 10, 527-539. doi: 10.1037//0882-7974.10.4.527

Spilich, G. J. (1983). Life span components of text processing: Structural and procedural differences. Journal of Verbal Learning and Verbal Behavior, 22, 231-244. doi: 10.1016/S0022-5371(83)90178-0Get

Talarico, M.J., Berntsen, D. ve Rubin, D.C. (2009). Positive emotions enhance recall of peripheral details. Cognition and Emotion, 23, 380-398. doi: 10.1080/02699930801993999

Talarico, J. M. ve Rubin, D. C. (2003). Confidence, not consistency, characterizes flashbulb memories. Psychological Science, 14, 455-461. doi: 10.1111/1467-9280.02453

Talarico, J. M. ve Rubin, D. C. (2007). Flashbulb memories are special after all; in phenomenology, not accuracy. Applied Cognitive Psychology, 21(5), 557-578. doi: 10.1002/acp.1293 
Talmi, D. ve Moscovitch, M. (2004). Can semantic relatedness explain the enhancement of memory for emotional words? Memory and Cognition, 32(5), 742-751. doi: 10.3758/BF03195864

Tekcan, A. I., Ece, B., Gülgöz, S. ve Er, N. (2003). Autobiographical and event memory for 9/11: Changes across one year. Applied Cognitive Psychology, 17, 1057-1066. doi: 10.1002/acp.985

Tulving, E. (1972). Episodic and semantic memory. E. Tulving ve W. Donaldson (Ed.), Organization of memory içinde (s. 382-403). New York, NY: Academic Press.

Tulving, E. (1995). Organization of memory: Quo vadis? M. S. Gazzaniga (Ed.), The Cognitive neurosciences içinde (s. 753-847). Cambridge, MA: The MIT Press.

Tulving, E., Schacter, D. L., McLachlan, D. R. ve Moscovitch, M. (1988). Priming of semantic autobiographical knowledge: A case study of retrograde amnesia. Brain and Cognition, 8, 3-20. doi: 10.1016/0278-2626(88)90035-8

Vecchiato, G., Astolfi L., De Vico Fallani, F., Cincotti, F., Mattia, D., Salinari, S., ... Babiloni, F. (2010). Changes in Brain Activity During the Observation of TV Commercials by Using EEG, GSR and HR Measurements. Brain Topography 23(2), 165-79. doi: 10.1007/s10548-009-0127-0

Wessel, I. ve Merckelbach, H. (1998). Memory for threat relevant and threat-irrelevant cues in spider phobics. Cognition and Emotion, 12, 93-104. doi: 10.1080/026999398379790

Winograd, E. ve Killinger, W. A. (1983). Relating age at encoding in early childhood to adult recall: Development of flashbulb memories. Journal of Experimental Psychology: General, 112, 413-422. doi: 10.1037/0096-3445.112.3.413

Zacks, R. T., Hasher, L. ve Li, H. (2000). Human memory. F. I. M. Craik ve T. A. Salthouse (Ed.), The handbook of aging and cognition içinde (s. 293-357). London, UK: Erlbaum.

Zelinski, E. M., Light, L. L. ve Gilewski, M. J. (1984). Adult age differences in memory for prose: The question of sensibility to passage structure. Developmental Psychology, 20(6),doi:10.1037/00121649.20.6.1181 
Ek 1. Araştırmada Kullanılan Toplumsal Olayların Listesi

\begin{tabular}{|l|l|}
\hline \multicolumn{2}{|l|}{ Genç (18-25) } \\
\hline 2004 & Sakıp Sabancı'nın Ölümü \\
\hline 1998 & İnsan Hakları Derneği Genel Başkanı'na Silahlı Saldırı \\
\hline 1999 & Barış Manço'nun Ölümü \\
\hline 2001 & Üzeyir Garih Cinayeti \\
\hline 2002 & Süreyya Ayhan'ın Altın Madalya Alması \\
\hline 2006 & Orhan Pamuk'un Nobel Edebiyat Ödülü'nü Alması \\
\hline 2010 & Deniz Baykal'ın İstifası \\
\hline 1999 & Muhsin Yazıcıŏlu'nun Helikopter Kazası Sonucu Ölümü \\
\hline 1998 & Aktütün Saldırısı \\
\hline 2011 & İbrahim Tatlıses'e Silahlı Saldırı \\
\hline
\end{tabular}

\begin{tabular}{|l|l|}
\hline \multicolumn{2}{|l|}{ Orta yaş (40-55) } \\
\hline 1980 & 12 Eylül Darbesi \\
\hline 2002 & Süreyya Ayhan'ın Altın Madalya Alması \\
\hline 1988 & Fatih Sultan Mehmet Köprüsü'nün Açılması \\
\hline 2011 & İbrahim Tatlıses'e Silahlı Saldırı \\
\hline 1984 & İlk PKK Saldırısı \\
\hline 2004 & Sakıp Sabancı'nın Ölümü \\
\hline 1976 & İstanbul-Antalya Seferini Yapan THY Uçağının Düşmesi \\
\hline 1998 & İnsan Hakları Derneği Genel Başkanı'na Silahlı Saldırı \\
\hline 1090 & Türkiye'nin İlk Kez Özel TV Kanalının Test Yayının Başlaması \\
\hline 1993 & Uğur Mumcu Suikastı \\
\hline
\end{tabular}

\begin{tabular}{|l|l|}
\hline \multicolumn{2}{|l|}{ İleri yaş (60-75) } \\
\hline 1980 & 12 Eylül Darbesi \\
\hline 2004 & Sakıp Sabancı'nın Ölümü \\
\hline 1959 & Başbakan Adnan Menderes'in Uçağının Düşmesi \\
\hline 1990 & Türkiye'nin İlk Kez Özel TV Kanalının Test Yayının Başlaması \\
\hline 1976 & İstanbul-Antalya Seferini Yapan THY Uçağının Düşmesi \\
\hline 1988 & Fatih Sultan Mehmet Köprüsü'nün Açılması \\
\hline 1967 & 6. Filonun İstanbul Limanı'na Gelmesinin Protesto Edilmesi \\
\hline 2011 & İbrahim Tatlıses'e Silahlı Saldırı \\
\hline 1965 & Sadun Boro Teknesiyle Dünya Turuna Çıktı \\
\hline 1998 & İnsan Hakları Derneği Genel Başkanı'na Silahlı Saldırı \\
\hline
\end{tabular}


Ek 2. Araştırmada Her Bir Toplumsal Olay İçin Kullanılan Soru Formlarından Bir Örnek

\section{Olay Içeriğine İlişkin (SB) Sorular}

OLAY: İbrahim Tatlıses'e silahlı saldırı

1. Bu olayı biliyor musunuz?

( ) Evet ( ) Hayır (Bir sonraki olaya geçin)

2. Peki. bu olayı hatırlıyor musunuz?

( ) Evet ( ) Hayır (Sadece çizgiye kadar olan 5 soruyu sorun)

3. Bu olay hangi tarihte oldu?

4. İbrahim Tatlises nerede vuruldu?

5. Olay saat kaç civarında oldu?

6. Saldırganlar kaç kişiydi?

7. Bu saldırıda İbrahim Tatlıses neresinden yaralandı?

\section{Olayın Haber Alındı̆̆ı Anın Hatırlanmasına İlişkin (EB) Sorular}

Siz bu olayı nasıl haber aldınız?

Bu olayı duyduğunuzda neredeydiniz?

\section{Olayın Hatırlanması Sırasındaki Heyecanlanma Düzeyi (Öz-bildirim)}

Peki. bu olayı duyduğunuzda ne kadar heyecanlandınız?

\begin{tabular}{|l|l|l|l|l|}
\multicolumn{1}{r}{ Hiç } & \multicolumn{1}{c}{ Az } & \multicolumn{1}{c}{ Orta } & \multicolumn{2}{c|}{ Oldukça } \\
\hline 1 & 2 & 3 & 4 & 5 \\
\hline
\end{tabular}

\section{Olayın Özelliklerine İlişkin (Fenomonolojik) Sorular}

Bu olayda hissettiğiniz duygular ne kadar yoğundu?

\begin{tabular}{|l|l|l|l|l|}
\multicolumn{1}{r}{ Hiç } & \multicolumn{1}{c}{ Az } & \multicolumn{1}{c}{ Orta } & \multicolumn{1}{c}{ Oldukça } & Çok \\
\hline 1 & 2 & 3 & 4 & 5 \\
\hline
\end{tabular}

Şu anda bu olayı hatırlarken duygularınız ne kadar yoğun?

\begin{tabular}{|l|l|l|l|l|}
\multicolumn{1}{r}{ Hiç } & \multicolumn{1}{c}{ Az } & \multicolumn{1}{c}{ Orta } & \multicolumn{2}{c}{ Oldukça } \\
\hline 1 & 2 & 3 & 4 & 5 \\
\hline
\end{tabular}

Bu olayın topluma olan etkisi ne kadar önemliydi?

\begin{tabular}{|l|l|l|l|l|}
\multicolumn{1}{r}{ Hiç } & \multicolumn{1}{c}{ Az } & \multicolumn{1}{c}{ Orta } & \multicolumn{2}{c}{ Oldukça } \\
\hline 1 & 2 & 3 & 4 & 5 \\
\hline
\end{tabular}

Bu olay sizin için ne kadar önemliydi?

\begin{tabular}{|l|l|l|l|l|}
\multicolumn{1}{r}{ Hiç } & Az & Orta & \multicolumn{2}{c|}{ Oldukça } \\
\hline 1 & 2 & 3 & 4 & 5 \\
\hline
\end{tabular}

$\begin{aligned} & \text { Çok } \\
& \text { olumsuz }\end{aligned}$
\begin{tabular}{|l|l|l|l|l|} 
Olumsuz Nötr & Olumlu & $\begin{array}{l}\text { Çok } \\
\text { olumlu }\end{array}$ \\
\hline-2 & -1 & 0 & 1 & 2 \\
\hline
\end{tabular}

Bu olay ne derece olumlu ya da olumsuz? 
Toplumsal Olaylara Dair Episodik ve Semantik Bellek Süreçlerinin Heyecanlanma Düzeyi ile Illişkisinin Yaş ve Heyecanın ... 